\title{
FLUID INCLUSION EVIDENCE FOR THE TEMPERATURE AND COMPOSITION OF ORE FLUIDS IN THE LEMHI PASS AND DIAMOND CREEK REE-TH DIS- TRICTS, IDAHO-MONTANA
}

A Thesis
presented to
the Faculty of the Graduate School
at the University of Missouri-Columbia

In Partial Fulfillment

of the Requirements for the Degree

Master of Science

by

GRACE K. ALLISON

Dr. Martin Appold, Thesis Supervisor

December, 2019 
The undersigned, appointed by the dean of the Graduate School, have examined the thesis entitled

FLUID INCLUSION EVIDENCE FOR THE TEMPERATURE AND COMPOSITION OF ORE FLUIDS IN THE LEMHI PASS AND DIAMOND CREEK REE-TH DISTRICTS, IDAHO-MONTANA

Presented by Grace K Allison, A candidate for the degree of Master of Science

And hereby certify that, in their opinion, it is worth of acceptance.

Dr. Martin S. Appold

Dr. Peter I. Nabelek

Dr. Michael D. Glascock 


\section{Acknowledgements}

I would like to thank Dr. Martin Appold for all the guidance and assistance during the process of this degree. There were many hours spent in his office and various jumping jack exercises to turn on the eco-friendly motion sensor lighting to get the science juices flowing. I would also like to thank Dr. Virginia Gillerman of the Idaho Geological Survey for her assistance in collecting samples from various sites in the Lemhi Pass and Diamond Creek districts. Without her guidance during the beginning stages of this project, many of the fluid inclusion-bearing samples would never have been found and traversing the dirt roads would not have been possible without an off-roading adventure in her Jeep. I would also like to thank Dr. Hector Lamadrid of the University of Missouri for brainstorming sessions and traversing the new world of Raman spectroscopy in Dr. Brice Lacroix's lab at Kansas State University, which Brice graciously let us use at no cost. I would like to give a big thank you to Dr. Iain Samson of the University of Windsor for his help in collecting the LA-ICP-MS data and his overall collaborative efforts. Lastly, I would like to thank my friends and family for all of their support. Though they may not have understood the details of fluid inclusions, Raman spectroscopy, or what is so special about thorium, they were willing to listen and nod along with my explanations. 


\section{Table of Contents}

ACKNOWLEDGEMENTS ...................................................................................

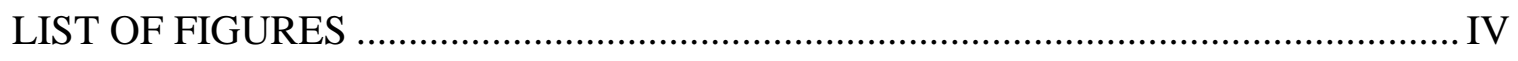

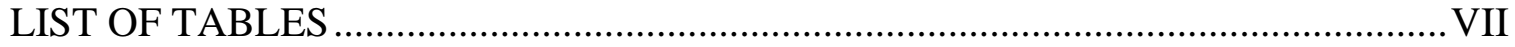

ABSTRACT .................................................................................................. VII

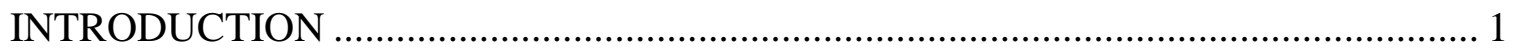

GEOLOGICAL BACKGROUND AND MINING HISTORY .................................... 4

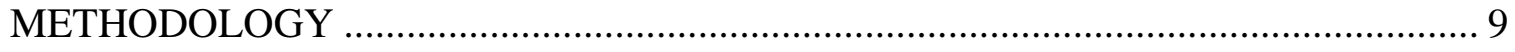

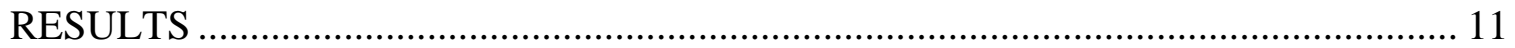

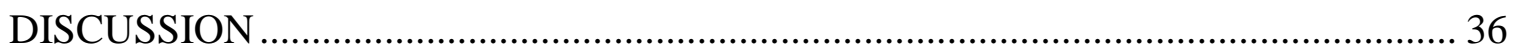

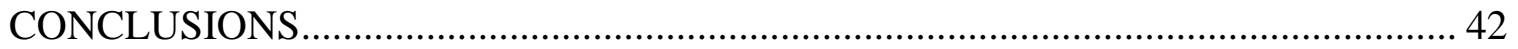

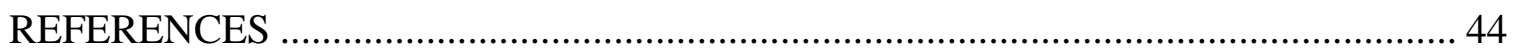

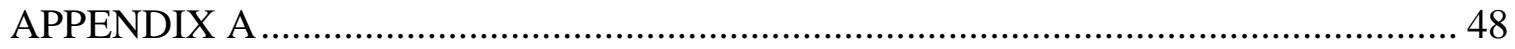




\section{List of Figures}

Figure 1. Map of Lemhi Pass and Diamond Creek Th-REE districts................. 1

Figure 2. View of Lemhi Pass from the Diamond Creek district...................... 3

Figure 3. Photographs of the Lemhi Pass Lucky Horseshoe vein with limonite coating the outcrop and a typical quartz vein from Lemhi Pass........................ 7

Figure 4. Photographs of rocks from the Diamond Creek district................... 8

Figure 5. Paragenetic sequence for the Lemhi Pass and Diamond Creek districts......... 11

Figure 6.Petrographs of apatite in quartz and chlorite in fluorite.................... 12

Figure 7. Photographs of representative fluid inclusion assemblages................ 14

Figure 8. Salinities of fluid inclusions from Lemhi Pass and Diamond Creek.......... 16

Figure 9. Homogenization temperatures of fluid inclusions from Lemhi Pass and

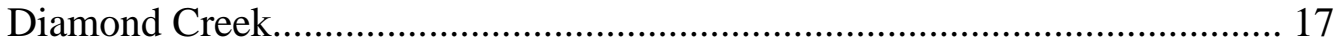

Figure 10. Representative Raman spectra for fluid inclusion vapor bubbles from Diamond Creek fluorite and Lemhi Pass quartz ............................... 22

Figure 11. $\mathrm{Na}, \mathrm{Ca}$, and $\mathrm{Pb}$ spectra from a LA-ICP-MS analysis of a fluorite-hosted fluid inclusion from Diamond Creek ...................................... 23 
Figure 12. Box plots showing the concentrations of major elements, base metals, REE's, $\mathrm{Th}$, and $\mathrm{U}$ in quartz and fluorite from Lemhi Pass and Diamond Creek

Figure 13. Photograph of mafic igneous rock associated with carbonatite in the Lemhi Pass district.

Figure 14. Comparison of the element:Naatomic ratios in Lemhi Pass and Diamond Creek fluid inclusions to major crustal fluid types...................... 32

Figure 15. Comparison of the compositions of fluid inclusions from Lemhi Pass and Diamond Creek with those of fluid inclusions from hydrothermal quartz and fluroite associated with carbonatite in the Tuva region, south-central Russia.

Figure 16. Comparison of REE concentrations in fluorite from Diamond Creek with those in fluorite from the Illinois-Kentucky MVT district.

Figure 17. Plots showing the concentrations of $\mathrm{Na}, \mathrm{Ca}, \mathrm{Mg}, \mathrm{Sr}$, and $\mathrm{K}$ versus total dissolved solids content in fluid in-clusions from Lemhi Pass and Diamond Creek relative to the fields of typical sedimentary brine compositions

Figure 18. Plot of average salinity and homogenization temperature of fluid inclusion assemblages from Lemhi Pass and Diamond Creek compared to fields of major crustal fluid types 36

Figure 19. Density isochores determined for Diamond Creek and Lemhi Pass fluid inclusions.

Figure 20. Calculated Lemhi Pass ore fluid $\delta^{18} \mathrm{O}$ values plotted relative to the $\delta^{18} \mathrm{O}$ values of magmatic, metamorphic, meteoric, and sedimentary basinal waters. 38 
Figure 21. Saturation index plot Saturation Index (SI) as a function of $\mathrm{pH}$ at a temperature of $200^{\circ} \mathrm{C}$ for select minerals pertinent to Lemhi Pass ore formation...... 39

Figure 22. Calculated concentrations of major aqueous Th and REE species as a function

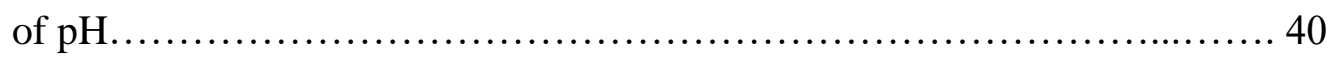




\section{List of Tables}

Table 1. Sample key and localitites........................................ 9

Table 2. Microthermometry results for quartz hosted fluid inclusions from Diamond Creek............................................................. 19

Table 3. Microthermometry results for fluorite and apatite-hosted fluid inclusions from Diamond Creek.......................................................... 20

Table 4. Microthermometry results for quartz-hosted fluid inclusions from Lucky Horseshoe mine in the Lemhi Pass district.............................. 21

Table 5. LA-ICP-MS and microthemometry results for quartz and fluorite hosted FIA's from Diamond Creek and Lemhi Pass. Concentrations in ppm............... 25

Table 6. Elemental compositions of fluorite and quartz from Lemhi pass and Diamond Creek determined by LA-ICP-MS. 


\begin{abstract}
The Lemhi Pass district is the largest thorium (Th) and $5^{\text {th }}$ largest rare earth element (REE) occurrence in the U.S., straddling the continental divide along the central Idaho-Montana border. The Diamond Creek district, thought to be genetically related to Lemhi Pass, is the $19^{\text {th }}$ largest known REE occurrence in the U.S., has substantially less thorium, and is located about $28 \mathrm{~km}$ northwest of the Lemhi Pass district. Thorium mineralization in both districts occurs predominately as thorite $\left(\mathrm{ThSiO}_{4}\right)$, and REE mineralization occurs predominantly as monazite ([Ce,La,Nd,Th]PO 4$)$. The Th-REE mineralization is hydrothermal and occurs in veins filling faults, fractures, and shear zones.
\end{abstract}

Three types of fluid inclusions were identified in the Lemhi Pass and Diamond Creek mineralization: (1) aqueous liquid + vapor, (2) aqueous liquid + vapor + halite, (3) aqueous liquid vapor + halite + an unidentified solid. Fluid inclusions from Diamond Creek were found to have salinities ranging from 16.8 to $23 \mathrm{NaCl}$ wt. \% equiv and homogenization temperatures ranging from about 120 to $259^{\circ} \mathrm{C}$. Quartz-hosted fluid inclusions from Lemhi Pass were found to have salinities ranging from 19.6 to $31.1 \mathrm{NaCl}$ wt. $\%$ equiv. Homogenization temperatures could not be measured for Lemhi Pass quartzhosted fluid inclusions as the fluid inclusions decrepitated at temperatures lower than the homogenization temperature. Insufficiently heterogeneous liquid:vapor bubble ratios in the fluid inclusions and their consistent homogenization to liquid and none to vapor indicate that the mineralizing fluids in Lemhi Pass and Diamond Creek did not boil. 
Based on previously reported ore formation temperatures of $350-525^{\circ} \mathrm{C}$, the microthermometry data obtained in the present study suggests a pressure of ore formation of 2.1 to 5.5 kbars.

Fluid inclusions in the Lemhi Pass and Diamond Creek deposits were found to be relatively rich in base metals, $\mathrm{CO}_{2}$, REE's, and thorium. The composition of the fluid inclusions fits best with a mixture of sedimentary brine and magmatic fluid, though the magmatic fluid is not clearly derived from a carbonatite as suggested in previous studies.

Chemical speciation modeling suggests that the Lemhi Pass and Diamond Creek ore fluids were moderately acidic, with a pH most likely between about 3.7 and 4.8. The modeling also showed that the REE's existed in solution mainly as chloride complexes and the thorium as a combination of chloride, phosphate and hydroxide complexes. Thus, dilution could have been an effective mechanism for precipitating the REE's and perhaps also thorium. Thorium precipitation could also have been promoted by the removal of phosphate from solution, perhaps by the precipitation of apatite. 


\section{Introduction}

The Lemhi Pass and Diamond Creek districts contain numerous hydrothermal rare earth element (REE) and thorium (Th) deposits located along the central part of the Idaho-Montana border in the U.S. (Fig. 1). Lemhi Pass is the larger of the two districts and represents the largest known occurrence of Th and the $5^{\text {th }}$ largest known occurrence

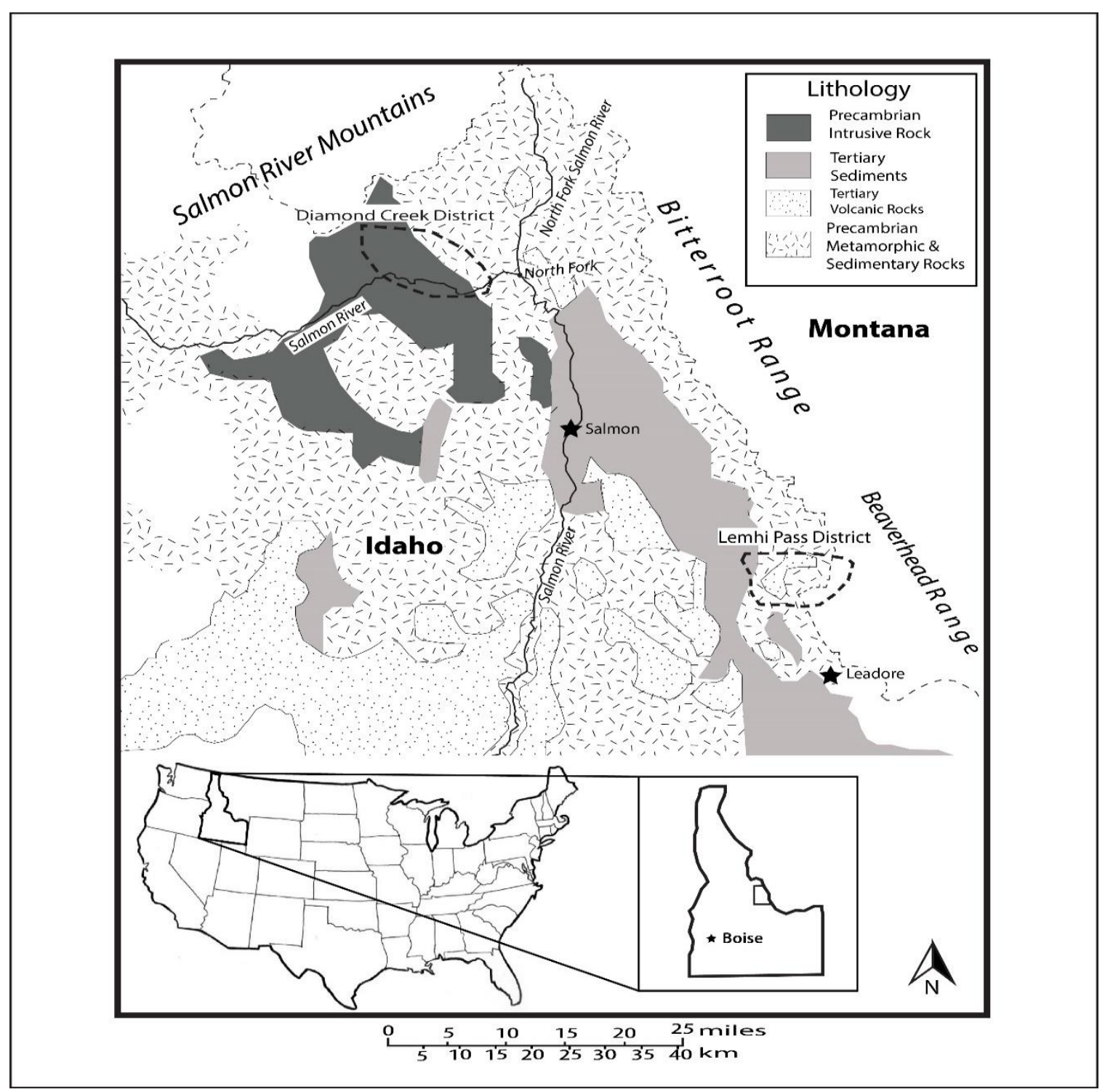

Figure 1: Simplified geological map of the Salmon River Valley region showing locations of the Lemhi Pass and Diamond Creek districts (adapted from Gillerman, 2008).

of REE's in the U.S (Castor et al., 2008; Gosen et. al 2009) . Diamond Creek is the $19^{\text {th }}$ 
largest known REE occurrence in the U.S. (Castor, 2008) and is located about $28 \mathrm{~km}$ northwest of the Lemhi Pass district, to which it is geologically similar and thought to be genetically related (Gillerman et al., 2006).

Fundamental to understanding the origin of these deposits is understanding the nature of the hydrothermal fluids that formed them. Although the Lemhi Pass and Diamond Creek districts have been well characterized geologically (Anderson 1958; Staatz 1979; Gillerman et al., 2007), little work has so far been done on the ore fluids. Most of what is known about the ore fluids comes from a study by Gibson (1998), who analyzed the chemical and isotopic composition of rocks and minerals from Lemhi Pass. This study suggests that the hydrothermal ore fluids were derived in part by exsolution from magma, had temperatures between 350 and $525^{\circ} \mathrm{C}$, had near neutral acidity, were oxidizing, and were relatively rich in phosphate and $\mathrm{Mg}$ but poor in $\mathrm{K}$ and $\mathrm{Ca}$. However, important questions about the ore fluids remain, such as their concentrations of other chemical species, including the principal ore elements, Th and the REE's, whether the ore fluids were anomalously rich in Th and REE's, the form in which Th and the REE's were held in solution and what mechanism caused their precipitation, the extent to which other types of crustal fluids, e.g. sedimentary brines, metamorphic fluids, were involved in ore formation, and the pressure of the ore fluid. In addition, the ore fluid temperature and composition reported by Gibson (1998) have large uncertainties, indicating a need for corroboration and refinement. A promising source of information about the properties of the Lemhi Pass and Diamond Creek ore fluids is fluid inclusions. However, no fluid inclusion studies for these districts have yet been published. 
The purpose of the present study was to characterize the chemical composition, temperature, and pressure of the fluids that formed the Lemhi Pass and Diamond Creek Th-REE deposits in order to gain insights into the deposits' origin. Specific questions of interest were whether the Lemhi Pass and Diamond Creek districts are genetically related, what kind of crustal fluid formed the deposits, whether the ore fluids were rich in Th and REE's, and what mechanism caused the precipitation of the Th and REE's. The study was carried out through analysis of fluid inclusions using petrography, microthermometry, Raman spectroscopy, laser ablation-inductively coupled plasma-mass spectrometry (LA-ICP-MS), and through chemical speciation modeling.

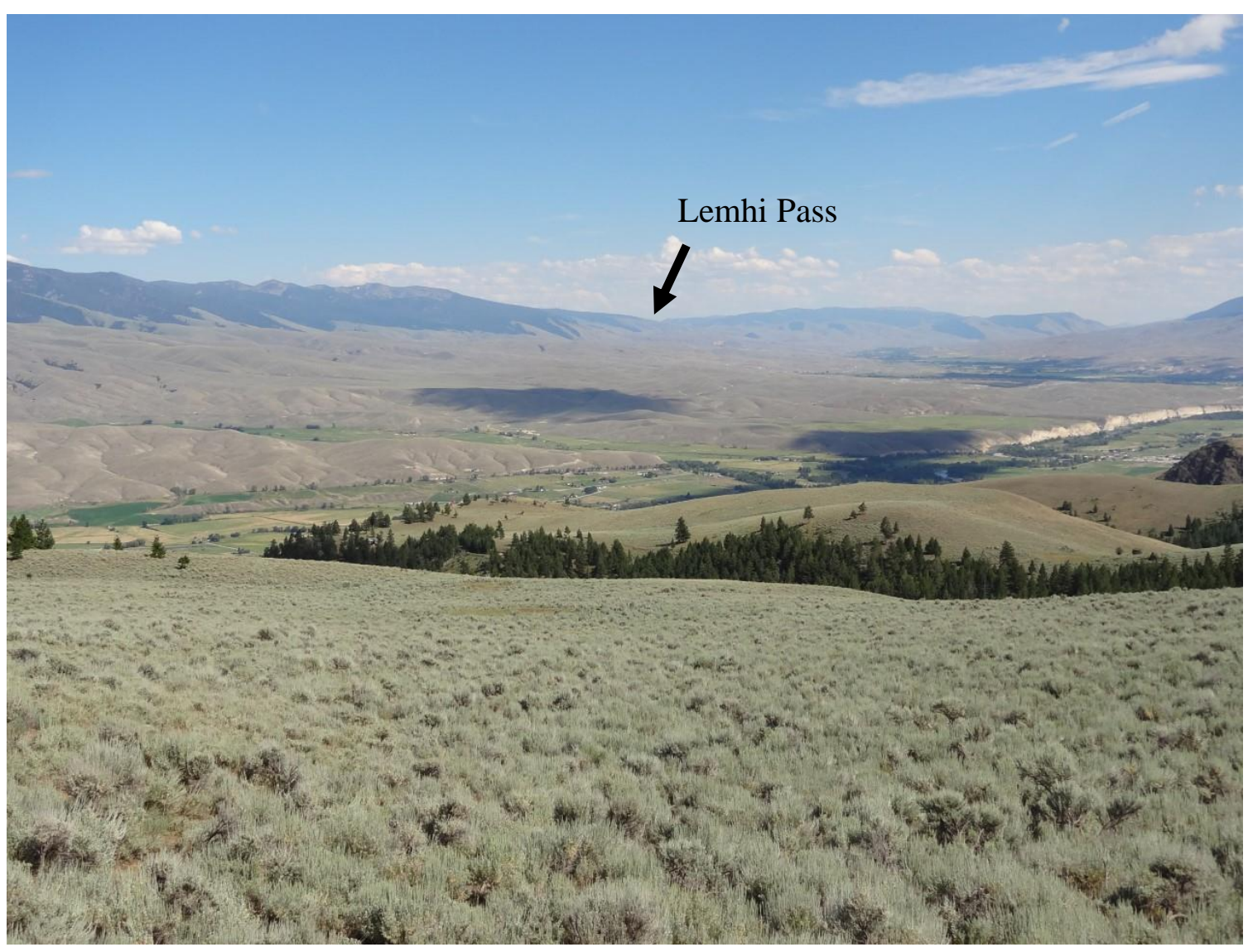

Figure 2: View of Lemhi Pass from the Diamond Creek district. 


\section{Geological Background and Mining History}

The geology of the Lemhi Pass and Diamond Creek districts and surrounding region has been described by Anderson (1958), Staatz (1979), Gillerman et al. (2002), and Gillerman (2008), and the following discussion is summarized from their work. Thorium and REE enriched rocks occur in an approximately $135 \mathrm{~km}$ long north-northwest-trending belt extending from about $16 \mathrm{~km}$ southeast of Leadore, Idaho to the Diamond Creek district (Fig. 1). Most of this Th and REE enrichment is concentrated in the Lemhi Pass district, which spans an area of $\sim 143 \mathrm{~km}^{2}$ in the central Beaverhead Mountains of the southern Bitterroot Range. Most of the Th-REE mineralization occurs in veins hosted by Proterozoic metasedimentary rocks, mainly quartzite and siltite, of the $6000 \mathrm{~m}$ thick Apple Creek and 1725 m thick Gunsight Formations (Gillerman, 2008). The siltite and quartzite are mineralogically similar, consisting of up to $80 \%$ quartz, with smaller amounts of plagioclase feldspar, biotite, and sericite, but differ in texture, with the siltites being much finer grained than the quartzites. The siltites tend to be greenish to black in color, due to the relative abundance of chlorite, whereas the quartzites tend to be light to medium gray. Siltite is also much less abundant than quartzite. In the southern part of the Beaverhead Mountains, including the southeast part of the Lemhi Pass district, the Mississippian Madison Limestone overlies the Proterozoic metasedimentary rocks. Elsewhere in the mineralized belt, the metasedimentary rocks are discontinuously overlain by the Tertiary Challis Volcanics, which consist of an older sequence of basalt, rhyodacite, tuff, and conglomerate, and a younger sequence of quartz latite flows and intrusives. Deposition of the Challis Volcanics was followed by deposition of Tertiary tuffaceous lacustrine sediments and intrusion of diorite dikes. The youngest rocks in the mineralized 
belt are Quaternary sediments, consisting of glacial deposits, landslide deposits, mudflows, and alluvium.

Thorium-REE mineralization in the Lemhi Pass district occurs in quartz, K-feldspar, iron oxide veins, of which a total of 219 have so far been documented. The veins occupy faults, fractures, and shear zones, are generally northwest striking and steeply dipping, and range in length from a few meters to over $1300 \mathrm{~m}$, with widths from hairline up to $12 \mathrm{~m}$ (Fig. 3). Thorium occurs principally in thorite ( $\left.\mathrm{ThSiO}_{4}\right)$, which may also contain significant concentrations of REE's. The thorite is typically closely associated with hematite and limonite (Fig. 3). Radioactivity at surface exposures of Th-mineralized areas visited in the present study could exceed 10 microSieverts per hour ( $\mu \mathrm{Sv} / \mathrm{h})$, but generally was much lower than that. Monazite ([Ce,La,Nd,Th]PO 4$)$ is the main host for REE's in the Lemhi Pass district, and the second most important host for thorium. Locally, allanite and brockite can be important mineral hosts for Th and REE's but are not prevalent throughout the district. Xenotime $\left([\mathrm{Y}, \mathrm{Th}] \mathrm{PO}_{4}\right)$ and bastnaesite $\left([\mathrm{Ce}, \mathrm{La}] \mathrm{CO}_{3} \mathrm{~F}\right)$ also host REE's but occur in only trace amounts in the district.

The age of the Th-REE mineralization in the Lemhi Pass district is uncertain. Gillerman (2008) performed Ar-Ar dating on K-feldspar from three thorium veins. The results suggest a primary K-feldspar crystallization age between 175 and 230 Ma (Jurassic-Triassic), followed by a 56 to $112 \mathrm{Ma}$ (Eocene-Cretaceous) reheating event. Gillerman also attempted to date monazite and thorite using Th-U-Pb geochronology. The results showed two age ranges, one from about 250 to $450 \mathrm{Ma}$ (Permian-Ordovician), with a mean of $355 \mathrm{Ma}$ (Mississippian), and the other from about 80 to $150 \mathrm{Ma}$ (CretaceousJurassic). Gillerman (2008) interpreted the older ages to represent the original Th-REE 
mineralization event, and the younger ages to represent a later recrystallization and remobilization event.

The Diamond Creek district is located on the eastern slope of the Salmon River Mountains, $\sim 28 \mathrm{~km}$ northwest of the Lemhi Pass district (Fig. 1). The Th-REE mineralization in the Diamond Creek district closely resembles that in the Lemhi Pass district and thus may be genetically related to it. The mineralization occurs in quartz, feldspar, hematite veins, where the hematite has been heavily weathered to limonite. The veins occur mainly in moderately to steeply dipping fractures and shear zones, though in Diamond Creek the veins strike to the northeast instead of to the northwest as in Lemhi Pass. Veins in the Diamond Creek district can be up to hundreds of meters long and over a meter wide, though most are smaller than that. Some Th-REE veins are contained in a Proterozoic granitic stock (Fig. 4) that intrudes older Proterozoic metasedimentary rock. Other Th-REE veins are contained in the metasedimentary rocks. As in Lemhi Pass, the principal Th-bearing mineral is thorite, which is closely associated with hematite and limonite, and the principal REE-bearing mineral is monazite. Radioactivity levels of ThREE mineralization exposed at the surface are similar to those in Lemhi Pass. The Diamond Creek deposits have not been radiometrically dated, but cannot be older than the Proterozoic granitic stock and metasedimentary rocks that host them.

According to Staatz (1972), Hedrick (2007), and Gosen (2009), the Lemhi Pass district contains approximately 70,550 tons of thorium oxide and is estimated to potentially hold 133,400 tons of thorium oxide. The largest veins in the Lemhi Pass district have an average $\mathrm{ThO}_{2}$ grade of $0.43 \%$, and account for $95 \%$ of the thorium resources that 
have been identified in the district thus far. The Lemhi Pass mineralization is characteristically enriched in the middle REE-group. In the Diamond Creek district, only eight veins have been identified, which contain 2,870 tons of total rare earth oxides (REO) with a potential resource of 75,500 tons of REO at an average grade of $1.22 \%$. Thorium in the Diamond Creek district has an average grade of $0.12 \%$.

The Lemhi Pass and Diamond Creek districts have attracted some commercial interest. Initially this was directed toward small showings of copper, gold, and silver discovered in 1883 and mined during the early $20^{\text {th }}$ century (Lewis et al., 2017). The largest of these is the Copper Queen mine, which has been dated at 1055 \pm 4 Ma (Gillerman et al., 2002), and thus appears unrelated to the Th-REE mineralization. Thorium was discovered in the district in 1949 through a U.S. Atomic Energy Commission survey, and the
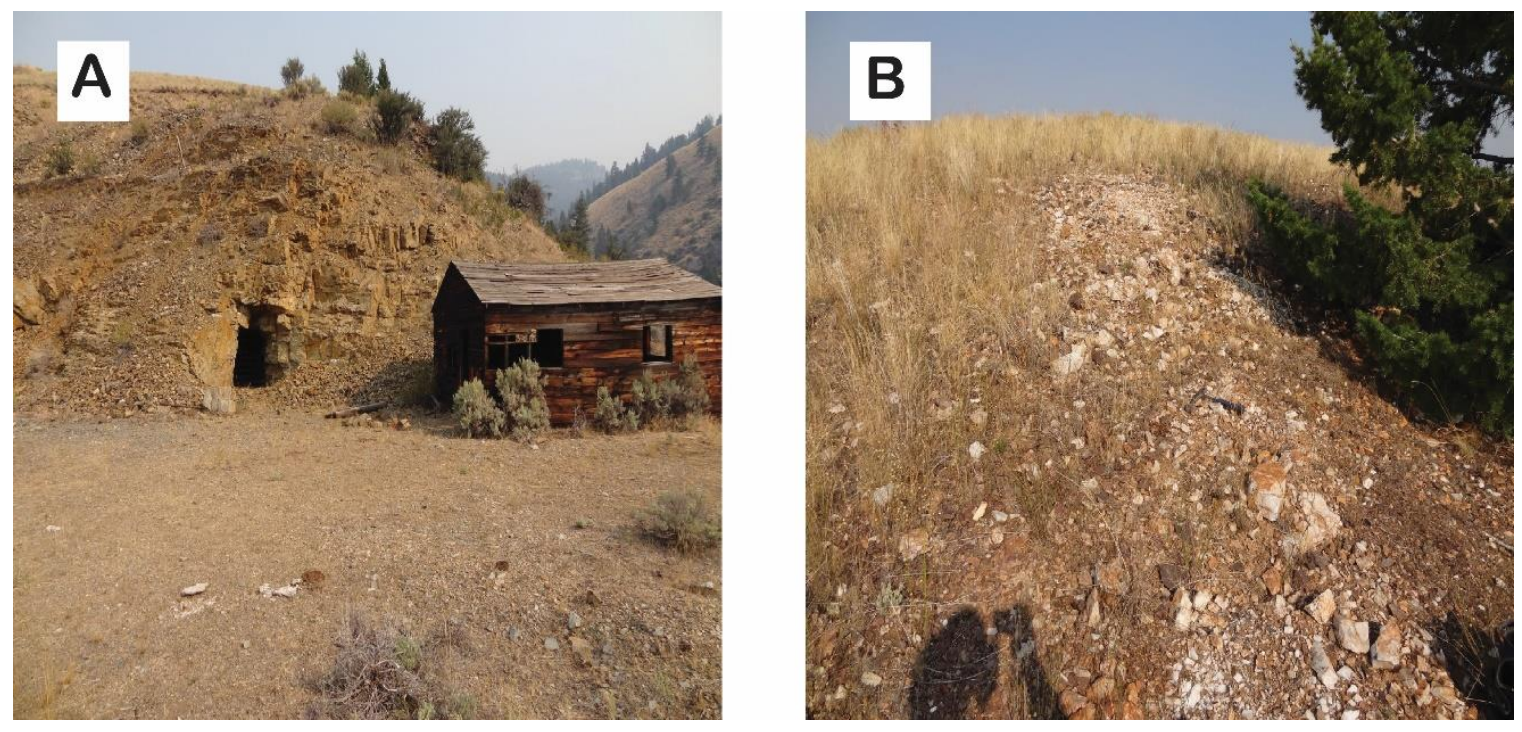

Figure 3: (A) Lemhi Pass Lucky Horseshoe mine with limonite coating the outcrop. (B) Typical quartz vein in Lemhi Pass, located on the continental divide. Most of the veins in the Lemhi Pass and Diamond Creek districts do not crop out well at the surface, and so most of the veins had to be trenched to expose them. Commonly, the veins are only visible as quartz float at the surface, as in (B).

district was heavily prospected during the 1950's and 1960's (Staatz, 1979). The REE enrichment of the district was documented by Anderson (1961). However, little mining 
of Th or REE's has occurred in the district, and none is occurring at present. The most recent commercial activity in the district consists of mineral exploration surveys conducted in the early 1980's and in 2008 (Lewis et al., 2017).
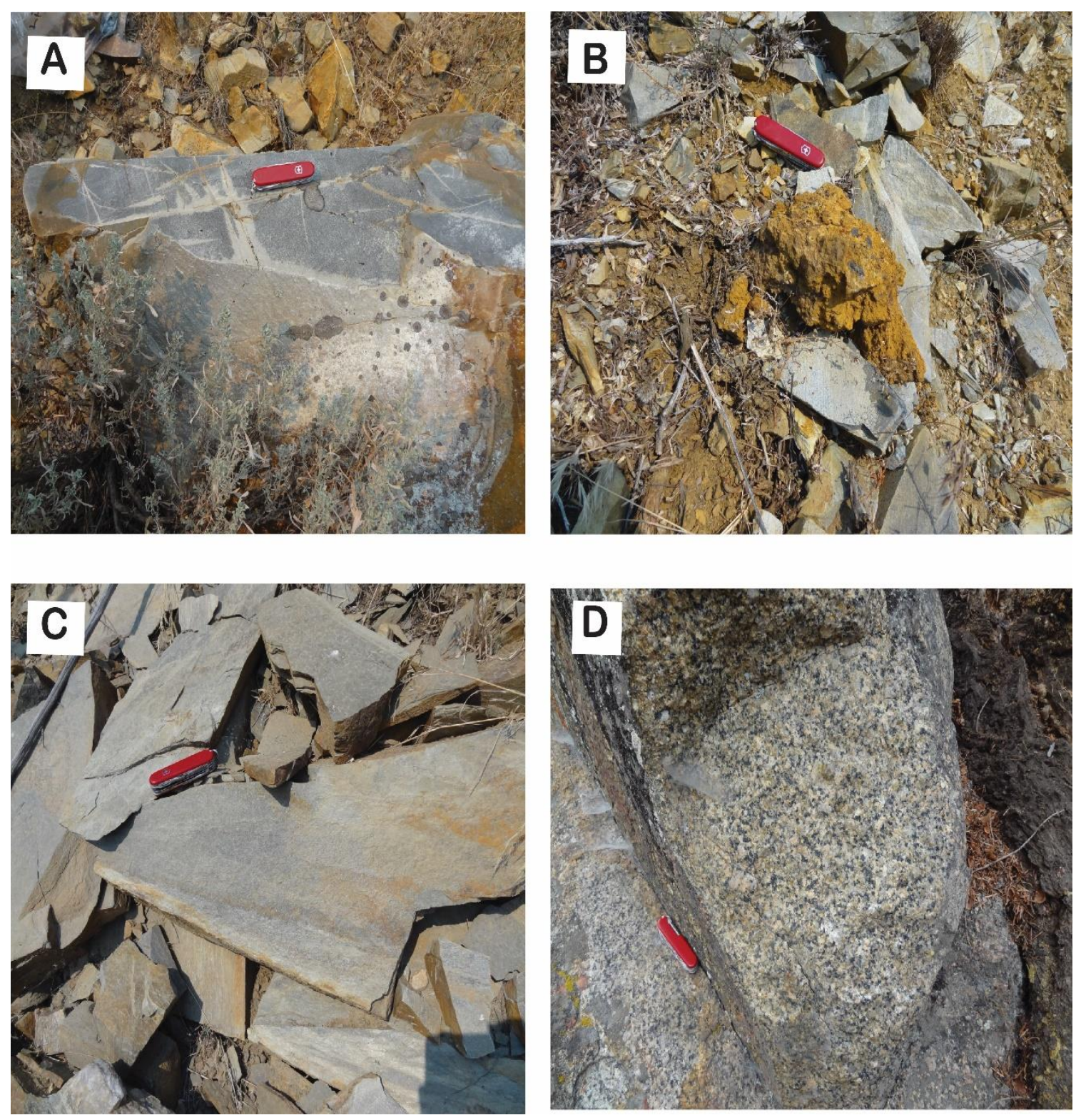

Figure 4: Photographs of rocks from the Diamond Creek district. (A) Metasomatically altered fractures in siltite, (B) limonite alteration of hematite commonly associated with thorium, (C) unaltered siltite, (D) granitic intrusion. 


\section{Methodology}

Samples analyzed in the present study were collected from two locations in Lemhi Pass and one location in Diamond Creek (Table 1). These locations were reported to be highly enriched in Th and REE's, and to contain quartz and fluorite, two transparent hydrothermal minerals with the potential to host usable fluid inclusions (Staatz, 1979, Gibson, 1998; Gillerman 2008). In addition, some quartz in Lemhi pass is reported to be paragenetically contemporaneous with the Th-REE minerals, thorite, monazite, and xenotime (Gibson, 1998). However, much of the quartz predates or postdates the Th-REE minerals, and some quartz may be unrelated to the Th-REE mineralization. Thus, detailed petrography was necessary in order to distinguish ore-stage from non-ore-stage quartz.

\begin{tabular}{llllllll}
\multicolumn{2}{l}{ Location name } & Sample ID Latitude (N) Longitude (W) & UTM Easting UTM Northing & UTM Zone & Datum 7.5 ' Quadrangle \\
\hline Apex Vein & LPAP-MS & 45.00975 & 113.50576 & 302535 & 4986871 & $12 T$ & WGS 84 Lemhi Pass, Idaho \\
Lucky Horseshoe & LP-LH-2 & 44.98928 & 113.49312 & 303467 & 4984783 & $12 T$ & WGS 84 Lemhi Pass, Idaho \\
Diamond Creek & LP-DC-C4 & 45.28515 & 113.95169 & 268519 & 5018867 & 12T & WGS 85 Salmon, Idaho \\
\hline \hline
\end{tabular}

Table 1: Locations of samples from the Diamond Creek and Lemhi Pass districts analyzed in the present study.

Samples for the present study where collected from outcrops and spoil heaps in mine and prospecting trenches documented by Staatz (1979), Gibson (1998) and Gillerman (2008) (Table 1). From these samples, doubly polished thin sections were prepared averaging $\sim 100 \mu \mathrm{m}$ in thickness.

Thin sections were then examined under a petrographic microscope to find primary fluid inclusion assemblages (FIA's) and to identify the paragenetic position of the host mineral. Once the FIA's has been located, photographed, and described, the thin sections were broken into 2-7 mm wide chips for microthermometry. 
Microthermometry was performed on a Linkham THMSG 600 heating-cooling stage at the University of Missouri-Columbia. The homogenization temperatures $\left(\mathrm{T}_{\mathrm{h}}\right)$ of all fluid inclusions in any chip were measured before any last-ice-melting temperatures $\left(\mathrm{T}_{\mathrm{m}}\right)$ were measured in order to avoid inducing error in the $\mathrm{T}_{\mathrm{h}}$ values caused by stretching of the fluid inclusions during freezing (Lawler and Crawford, 1983). The accuracy of the $\mathrm{T}_{\mathrm{h}}$ and $\mathrm{T}_{\mathrm{m}}$ measurements was calibrated using synthetic fluid inclusions produced by Dr. Ronald Bakker of the University of Leoben, Austria. Standards included the melting temperature of pure water $\left(0^{\circ} \mathrm{C}\right)$, the critical temperature of pure water $\left(374^{\circ} \mathrm{C}\right)$, the melting temperature of $\mathrm{CO}_{2}\left(-56.6^{\circ} \mathrm{C}\right)$, and the eutectic melting temperature for $\mathrm{H}_{2} \mathrm{O}$ $\mathrm{NaCl}\left(-21.2^{\circ} \mathrm{C}\right)$. The precision of the heating-freezing stage was $\sim 1.4^{\circ} \mathrm{C}$ for $\mathrm{T}_{\mathrm{h}}$ and $\sim 0.1^{\circ} \mathrm{C}$ for $\mathrm{T}_{\mathrm{m}}$. Last-ice melting temperatures were converted to $\mathrm{NaCl}$ equivalent weight percent (eq. wt \%) based on Bodnar (1993). Some fluid inclusions contained halite daughter crystals, and the salinity of these fluid inclusions was determined from the temperature of halite dissolution according to Sterner et al. (1988).

Raman spectroscopy was utilized to identify any molecular species present within the fluid inclusions. The Raman spectroscopy was performed in the Department of Geology at Kansas State University. Raman spectra were recorded with a Renishaw Invia Reflex microspectrometer equipped with $1800 \mathrm{~g} / \mathrm{mm}$ gratings and using $532 \mathrm{~nm}$ (green) laser excitation.

Measurement of the total concentrations of chemical elements in fluid inclusions was performed using an Agilent 7900 fast-scanning LA-ICP-MS with a $193 \mathrm{~nm}$ photon machine laser at the University of Windsor, Ontario, using a repetition rate of $180 \mathrm{~Hz}$, a burst count of 10,800 , a laser energy of $100 \%$, and a spot size of $25 \mu \mathrm{m}$. The following 
isotopes were targeted in the LA-ICP-MS analyses: ${ }^{23} \mathrm{Na},{ }^{24} \mathrm{Mg},{ }^{27} \mathrm{Al},{ }^{29} \mathrm{Si},{ }^{39} \mathrm{~K},{ }^{44} \mathrm{Ca},{ }^{47} \mathrm{Ti}$, ${ }^{48} \mathrm{Ti},{ }^{57} \mathrm{Fe},{ }^{63} \mathrm{Cu},{ }^{64} \mathrm{Zn},{ }^{85} \mathrm{Rb},{ }^{88} \mathrm{Sr},{ }^{121} \mathrm{Sb},{ }^{140} \mathrm{Ce},{ }^{146} \mathrm{Nd},{ }^{152} \mathrm{Sm},{ }^{153} \mathrm{Eu},{ }^{158} \mathrm{Gd},{ }^{159} \mathrm{~Tb},{ }^{174} \mathrm{Yb}$, ${ }^{204} \mathrm{~Pb},{ }^{232} \mathrm{Th}$, and ${ }^{238} \mathrm{U}$. The LA-ICP-MS measurements were calibrated using National Institute of Standards and Technology (NIST) standards 610 and 612, which were measured at the beginning and end of each analytical session to correct for instrumental drift. LA-ICP-MS analysis was carried out as bulk analyses of multiple fluid inclusions within FIA's rather than on individual fluid inclusions due to the small size of the fluid inclusions, limitations in the sensitivity of the laser operating system, and the frequency with which individual fluid inclusions did not open cleanly and produce a quantifiable signal.

\section{Results}

\section{Petrography}

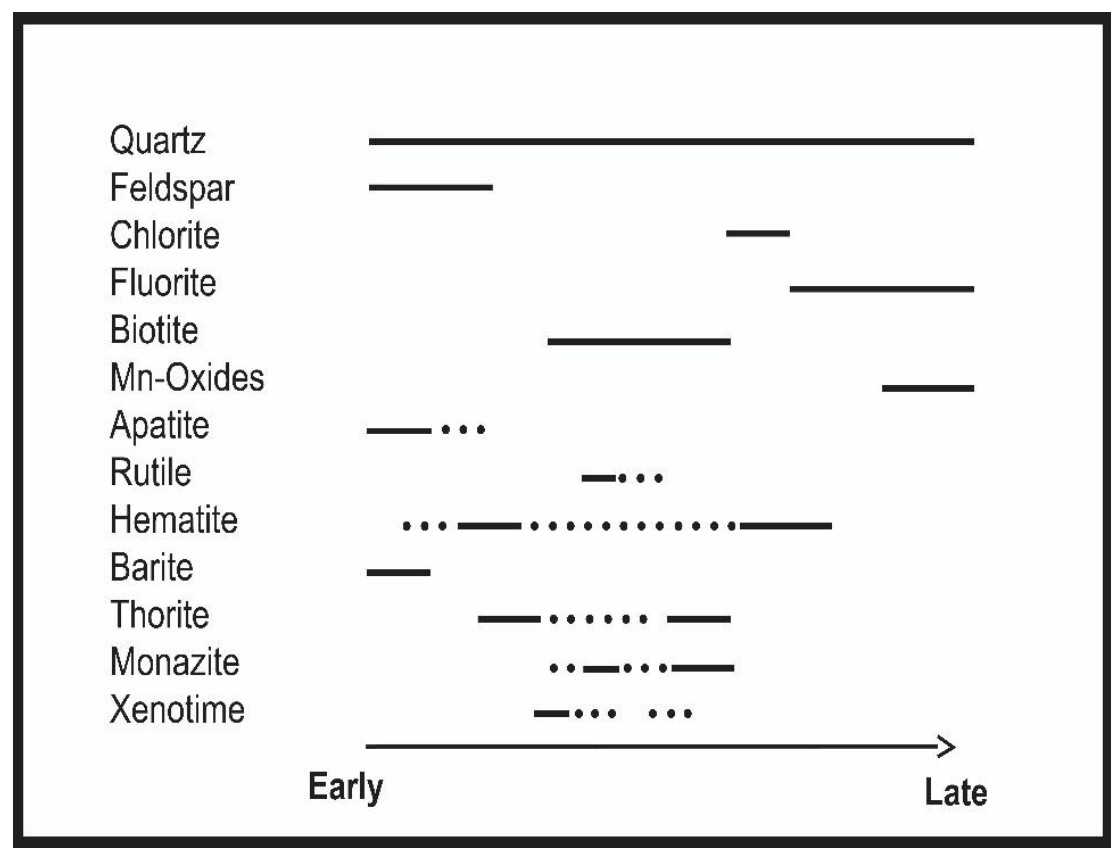

Thin sections from

Diamond Creek and

Lemhi Pass rock

samples were exam-

ined under a petro-

graphic microscope.

Fluid inclusions large

enough to be ana-

lyzed were overall

Figure 5: Paragenetic sequence for the Lemhi Pass and Diamond Creek districts. This paragenetic sequence (minus fluorite) was reported by Gibson (1998) for Lemhi Pass. The present study confirmed that this paragenetic sequence is also valid for Diamond Creek and determined the paragenetic position of fluorite.

rare in ore-stage

minerals in both

districts. Only 
fluorite from one prospect trench in the Diamond Creek district (sample LP-DC-C4) and quartz from the Lucky Horseshoe mine in the Lemhi Pass district (sample LP-LH-2) were found to contain usable fluid inclusions in confirmed ore-stage host minerals. Fluorite was not included in the paragenetic sequence for Lemhi Pass reported by Gibson (1998). However, in the present study, fluorite was determined to have been deposited during the later stages of the ore forming process because of the entrainment of paragenetically late chlorite inclusions within fluorite (Figs.5 and 6). Fluorite also commonly contains large, paragenetically early apatite crystals.
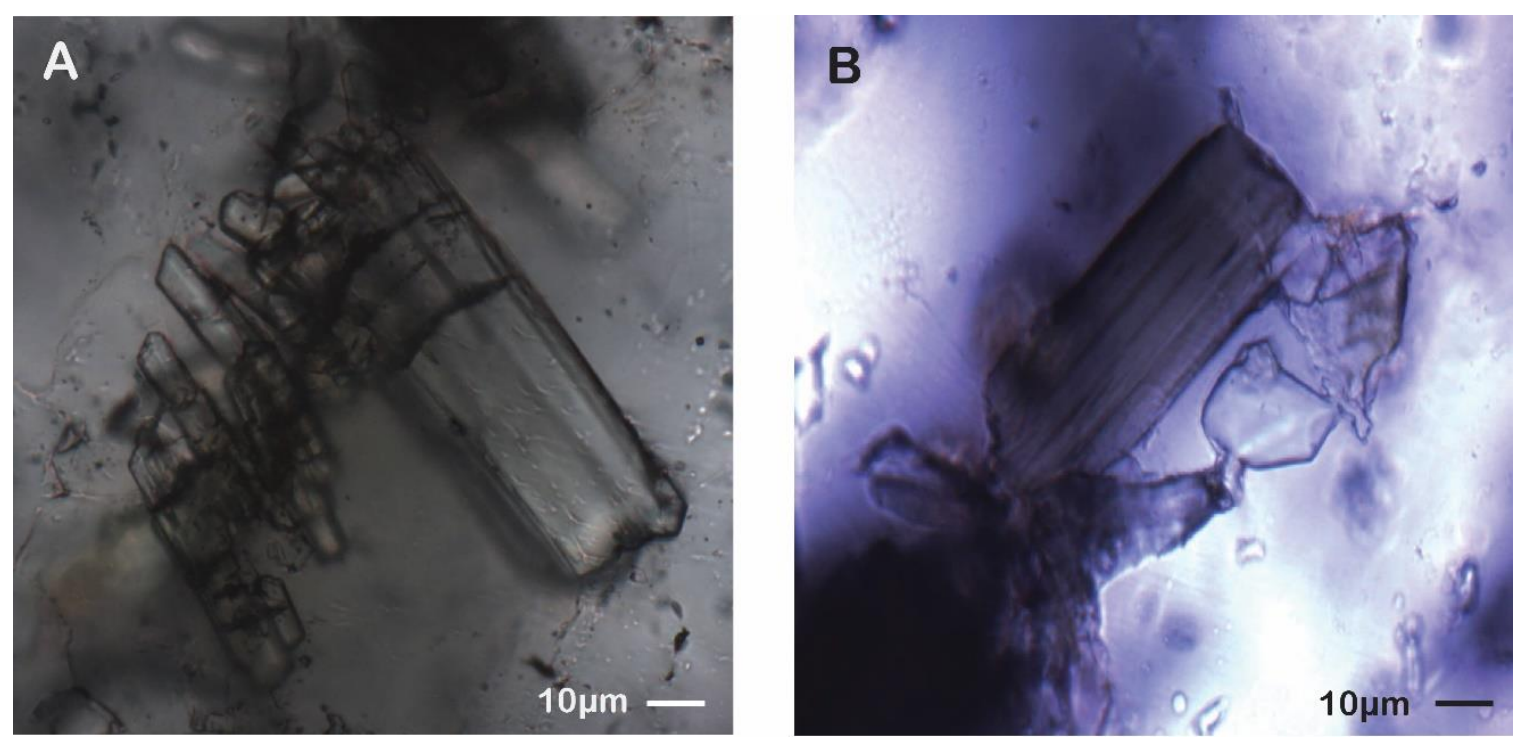

Figure 6: (A) Lemhi Pass quartz from sample LPLH-2 containing apatite crystals that are all oriented in the same direction, suggesting coeval formation of quartz and apatite, and thus, early formation of quartz in the paragenetic sequence. (B) Diamond Creek fluorite containing an inclusion of chlorite indicating that the fluorite formed after chlorite in the paragenetic sequence.

Quartz from both the Diamond Creek and Lemhi Pass districts tended to be more difficult to constrain paragenetically. Because quartz occurs throughout the entire paragenetic sequence, extra care had to be taken to establish its timing. In all of the Diamond Creek samples collected in the present study, quartz was found to crosscut fluorite, making the quartz younger than the fluorite. Thus, the maximum age for this quartz is post- 
fluorite. However, this quartz was not found to contain any features that would constrain its minimum age. Thus, the relationship of the Diamond Creek quartz collected in the present study to the Th-REE mineralization is unclear, though the quartz could possibly be as old as the youngest minerals in the Diamond Creek hydrothermal mineral assemblage. In contrast, in the Lemhi Pass district, quartz from the Lucky Horseshoe mine contained euhedral apatite crystals uniformly oriented approximately orthogonal to the edge of the quartz vein (Fig. 6A). This uniformity in crystal orientation suggests that the apatite formed at the same time as the quartz. In contrast, if the apatite crystals were older than the quartz and had been entrained within the quartz as accidental mineral inclusions, then the apatite crystals would likely appear in more random orientations.

Three types of fluid inclusions were observed in the Lemhi Pass and Diamond Creek districts: fluid inclusions containing (1) aqueous liquid and a vapor bubble (LV), (2) aqueous liquid, a vapor bubble, and a cube-shaped crystal interpreted to be a halite daughter crystal (LVH), (3) aqueous liquid, a vapor bubble, a likely halite daughter crystal, and an unidentified transparent, irregularly-shaped solid (LVHS). Halite crystals were identified based on their similar refraction index to that of quartz, which was evident when the halite crystals were in contact with the fluid inclusion boundary in quartz, making the fluid inclusion boundary invisible. 


\section{Microthermometry}

Fluid inclusion $T_{h}$ and $T_{m}$ values obtained in the present study are shown in Tables 2-4. Many fluid inclusions, particularly in quartz, that were heated to measure $\mathrm{T}_{\mathrm{h}}$ decrepitated between $\sim 218$ and $330^{\circ} \mathrm{C}$ before homogenizing. Thus, in the remaining chips from samples prone to fluid inclusion decrepitation, only $\mathrm{T}_{\mathrm{m}}$ was measured (Fig. 8).
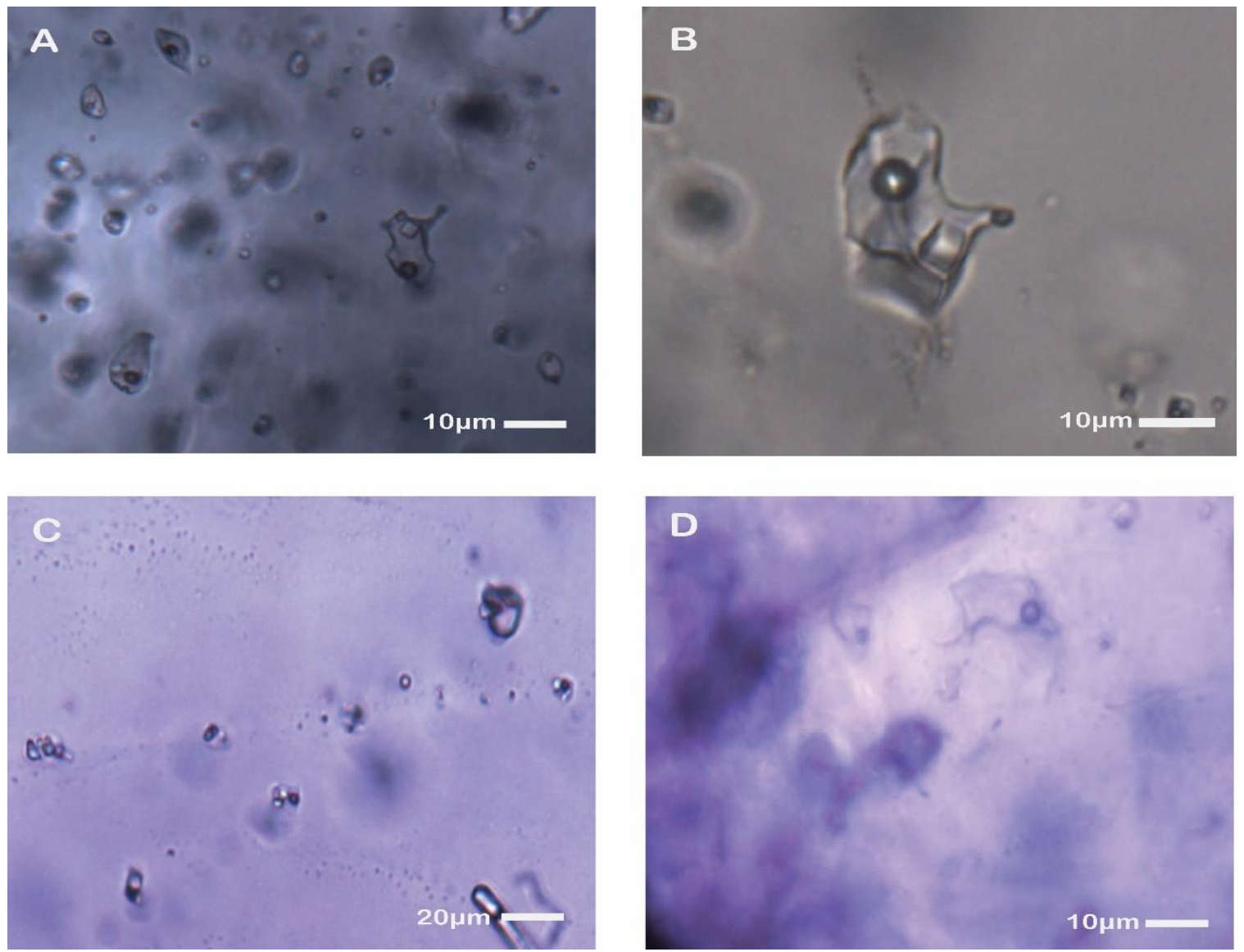

Figure 7: Representative fluid inclusion assemblages from Diamond Creek and Lemhi Pass. (A) LVH fluid inclusions in quartz from the Lucky Horseshoe mine. (B) Individual LVH fluid inclusion in quartz from the Lucky Horseshoe mine clearly showing cube-shaped daughter crystal. (C) LVHS fluid inclusions in fluorite from the Diamond Creek district. (D) LV fluid inclusions in fluorite from the Apex mine in the Lemhi Pass district.

Fluid inclusions in the Lemhi Pass Lucky Horseshoe vein were the largest observed in the present study, ranging in length from 3.3 to $40.4 \mu \mathrm{m}$. The fluid inclusions were mainly LVH-type and had relatively consistent liquid to vapor ratios. However, in 
all attempts to measure homogenization temperature, the fluid inclusions decrepitated before homogenizing, though the vapor bubble always shrank significantly upon heating. The observation of relatively consistent fluid inclusion liquid:vapor ratios in conjunction with the observation that fluid inclusions always approached homogenization to liquid and never to vapor suggests that the fluid that precipitated ore-stage quartz in the Lucky Horseshoe vein did not boil. This is important because boiling was proposed by Gibson (1998) as a potential precipitation mechanism for the Lemhi Pass Th-REE mineralization, mainly because of a $\mathrm{pH}$ increase incurred by the loss of acidic volatiles such as $\mathrm{CO}_{2}, \mathrm{H}_{2} \mathrm{~S}$, and $\mathrm{HCl}$. The presence of halite daughter crystals in the fluid inclusions allowed salinity to be determined from the temperature of halite dissolution, which ranged from 177.2 to $205.3^{\circ} \mathrm{C}$, corresponding to a salinity of 30.8 to $32 \mathrm{NaCl}$ wt. \% equiv. (Fig. 8).

Fluid inclusions from Diamond Creek were much smaller and difficult to locate than in the quartz from the Lemhi Pass Lucky Horseshoe vein. Usable fluorite-hosted fluid inclusions from Diamond Creek ranged in length mainly from about 1.7 to $11 \mu \mathrm{m}$, with the largest fluid inclusion reaching a length of about $21 \mu \mathrm{m}$ (Table 3). Many more fluid inclusions smaller than about $1 \mu \mathrm{m}$ were observed in the fluorite but were too small for microthermometry. All three fluid inclusion types were observed in fluorite from Diamond Creek, with LVHS fluid inclusions being the most common. However, salinities and homogenization temperatures were only obtained from LV fluid inclusions, as upon heating, halite-containing fluid inclusions decrepitated before the halite dissolved or the vapor bubble homogenized. Last ice melting temperatures in LV fluid inclusions range from -12.9 to $-21^{\circ} \mathrm{C}$, corresponding to salinities of 16.8 to $23 \mathrm{NaCl}$ wt. \% equiv (Fig. 8). Homogenization temperatures in LV fluid inclusions range from 119.5 to $259.4^{\circ} \mathrm{C}$. 
Thus, liquid:vapor ratios in LV fluid inclusions varied significantly, but not enough to indicate that boiling occurred. In addition, all of the LV fluid inclusions homogenized to liquid and none to vapor, providing further evidence against boiling. Homogenization temperatures in fluorite were between 119.5 to $259.4^{\circ} \mathrm{C}$ (Fig. 9).

Because the relationship of the Diamond Creek quartz collected in the present study to Th-REE mineralization is uncertain, the significance of fluid inclusion data from this quartz for the origin of Th-REE mineralization in Diamond Creek is also uncertain. Fluid inclusions in Diamond Creek quartz tend to be small, with lengths ranging from about 2 to $22 \mu \mathrm{m}$, though most fluid inclusions range in length from about 7 to $10 \mu \mathrm{m}$. Fluid inclusions consist of LV and LVH types. Microthermometry data were obtained for the LV fluid inclusions. Last ice melting temperatures range from -12 to $-17.3^{\circ} \mathrm{C}$,
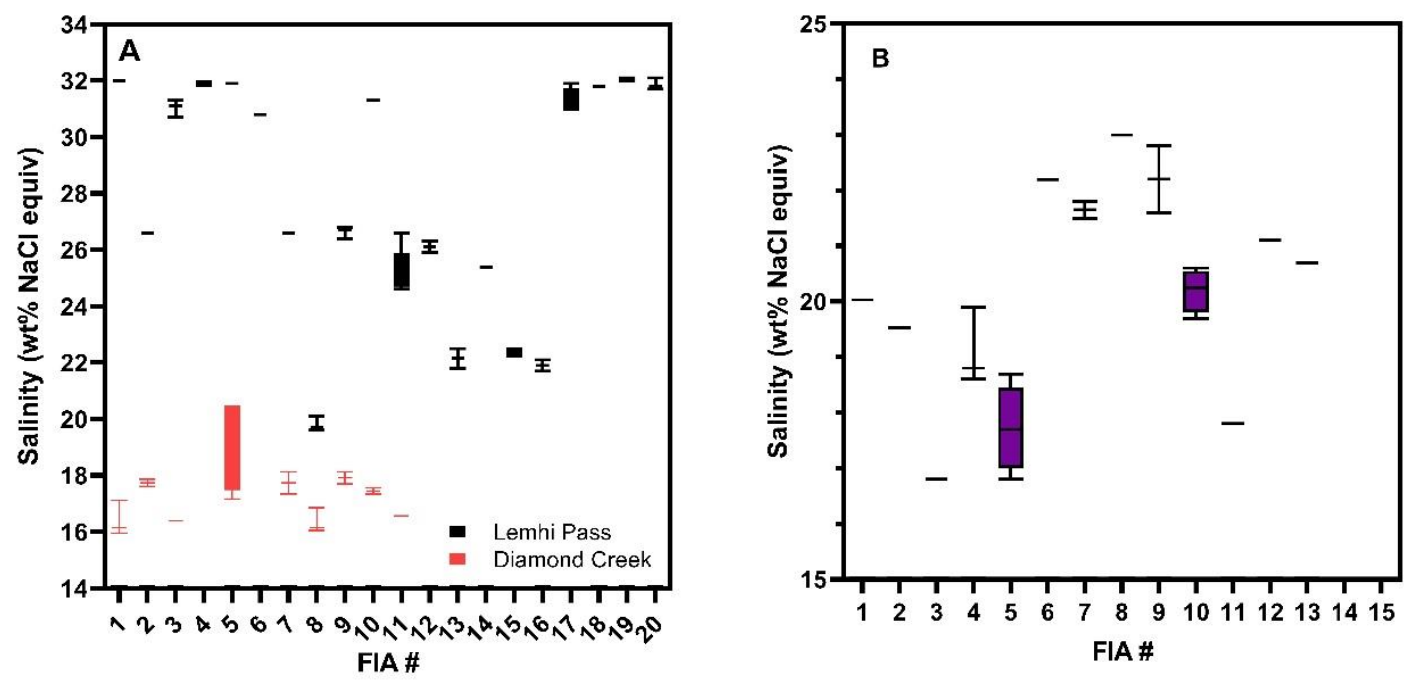

Figure 8: Salinities determined from microthermometry for (A) quartz-hosted fluid inclusions assemblages from Diamond Creek and Lemhi Pass, and (B) fluorite-hosted fluid inclusions from Diamond Creek. Fluid inclusion salinities in each district are highly variable. Because growth bands were not observed in either quartz or fluorite, variation of salinity as a function of time within each mineral host could not be evaluated. However, because Lemhi Pass quartz is paragenetically early and Diamond Creek fluorite is paragenetically late, this suggests that ore fluid salinity in the region may have decreased over time. 
corresponding to salinities of 16 to $20.4 \mathrm{NaCl}$ wt. \% equiv (Fig. 8). Homogenization temperatures range from 157.9 to $370.5^{\circ} \mathrm{C}$ (Fig. 9). As for the fluid inclusions in Diamond Creek fluorite and Lemhi Pass quartz described above, fluid inclusions in Diamond Creek quartz do not show evidence of boiling.

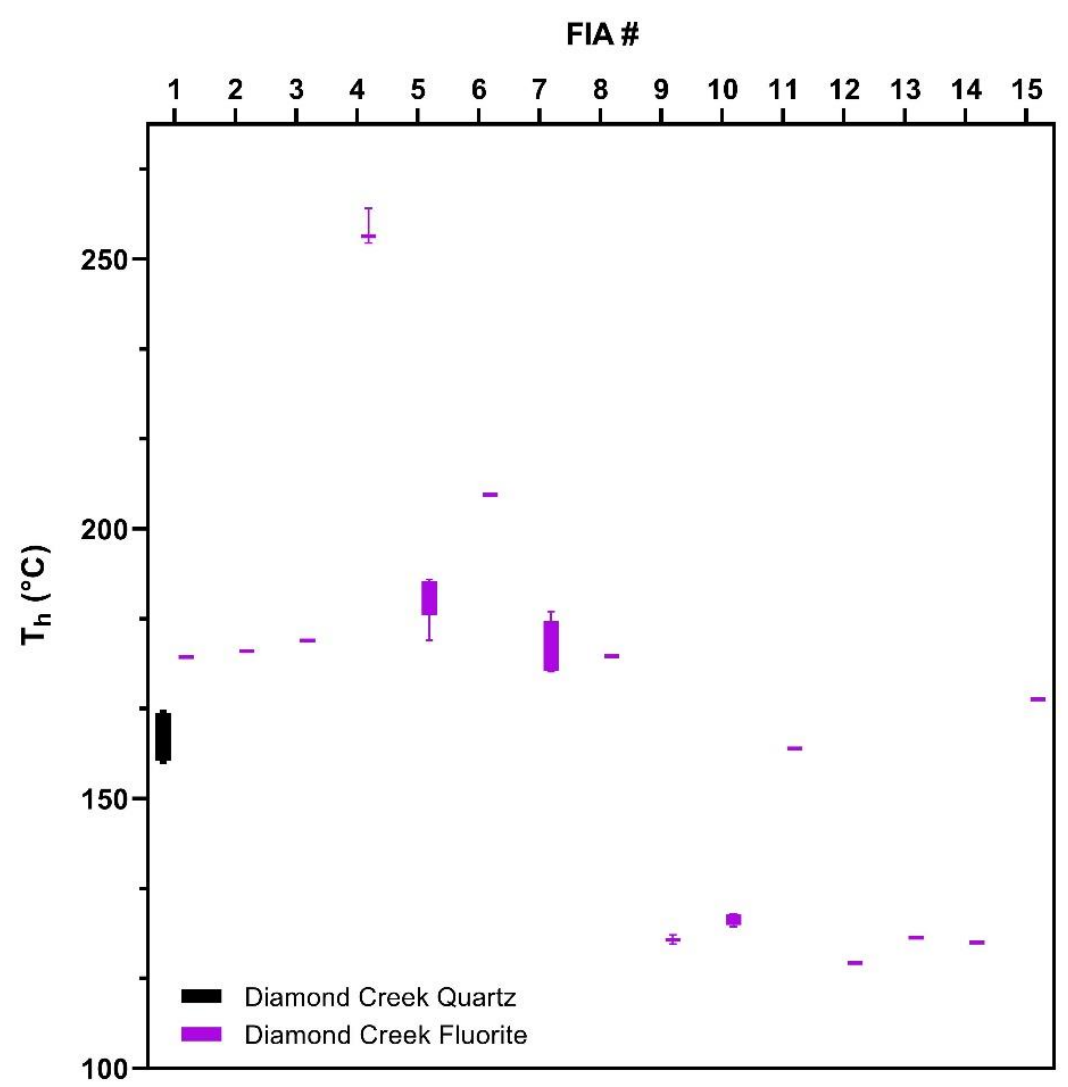

Figure 9: Homogenization temperatures for fluorite- and quartz-hosted fluid inclusion assemblages from Diamond Creek. Post-ore quartz, which has fluid inclusion homogenization temperatures of $\sim 371^{\circ} \mathrm{C}$, is not shown in this figure.

Raman spectroscopy

Raman spectroscopy was used to analyze the quartz- and fluorite-hosted fluid inclusions from both districts. Vapor bubbles in fluid inclusions from both districts and 
minerals were consistently found to contain $\mathrm{CO}_{2}$ and $\mathrm{N}_{2}$, with $\mathrm{CO}_{2}$ showing a stronger response than $\mathrm{N}_{2}$ (Fig. 10). Methane $\left(\mathrm{CH}_{4}\right)$, a common constituent in fluid inclusions in sediment-hosted base metal deposits, was not detected. Thus, mineralizing conditions in Lemhi Pass and Diamond Creek were oxidizing enough to favor the existence of $\mathrm{CO}_{2}$ over methane.

\section{LA-ICP-MS}

As noted in the methodology, LA-ICP-MS analysis was not performed on individual fluid inclusions because of the small size of most of the fluid inclusions, limitations in the sensitivity of the instrument, and a tendency for individual fluid inclusions not to open cleanly and produce a quantifiable signal. Instead, LA-ICP-MS analyses were performed using a laser beam diameter that was large enough to ablate multiple fluid inclusions in a primary FIA at once in order to produce a signal strong enough to be quantifiable. Thus, the LA-ICP-MS elemental concentrations reported in the present study (see Tables 5 and 6) are the products of composite signals from multiple fluid inclusions and thus can be considered to be bulk analyses. The chief elements of interest were thorium and the REE's, other elements that are part of the hydrothermal mineral assemblage, and typical major elements in hydrothermal fluids. 
Table 2: Microthermometry results for quartz-hosted fluid inclusions from Diamond Creek.

\begin{tabular}{|c|c|c|c|c|c|c|c|c|c|c|}
\hline Sample ID ${ }^{1}$ & Chip ID & FIA \# & $\begin{array}{c}\text { No. of } \\
\text { inclusions } \\
\text { in the } \\
\text { FIA }\end{array}$ & $\begin{array}{l}\text { width } \\
(\mu \mathrm{m})\end{array}$ & $\begin{array}{l}\text { length } \\
(\mu \mathrm{m})\end{array}$ & Host & $\begin{array}{c}\text { Average } \\
\operatorname{Tm}\left({ }^{\circ} \mathbf{C}\right)\end{array}$ & $\begin{array}{c}\text { Average } \\
\text { Th }\left({ }^{\circ} \mathbf{C}\right)\end{array}$ & $\begin{array}{c}\text { DM } \\
\text { Dissolve } \\
\left({ }^{\circ} \mathbf{C}\right)\end{array}$ & Salinity $^{2}$ \\
\hline LPDC C41 & $\mathrm{C}$ & 1 & & 5.1 & 12.0 & Quartz & -13.3 & - & - & 17.1 \\
\hline LPDC C41 & $\mathrm{C}$ & 1 & & 5.7 & 13.2 & Quartz & -12.2 & - & - & 16.1 \\
\hline LPDC C41 & $\mathrm{C}$ & 1 & 3 & 9.4 & 8.3 & Quartz & -12.0 & - & - & 16.0 \\
\hline LPDC C410 & $\mathrm{C}$ & 2 & & 22.2 & 15.2 & Quartz & -14.0 & - & - & 17.7 \\
\hline LPDC C410 & $\mathrm{C}$ & 2 & & 16.2 & 7.6 & Quartz & -14.1 & - & - & 17.9 \\
\hline LPDC C410 & $\mathrm{C}$ & 2 & 3 & 6.7 & 19.4 & Quartz & -13.8 & - & - & 17.6 \\
\hline LPDC C416 & A & 3 & & 6.3 & 6.3 & Quartz & - & - & - & - \\
\hline LPDC C416 & A & 3 & & 4.0 & 3.5 & Quartz & - & - & - & - \\
\hline LPDC C416 & A & 3 & 3 & 3.7 & 8.2 & Quartz & -12.5 & - & - & 16.4 \\
\hline LPDC C $416^{1}$ & A & 4 & 1 & 12.5 & 12.4 & Quartz & - & - & - & - \\
\hline LPDC C416 & $\mathrm{C}$ & 5 & & 6.3 & 7.7 & Quartz & -17.3 & 157.9 & - & 20.4 \\
\hline LPDC C416 & $\mathrm{C}$ & 5 & & 4.8 & 17.2 & Quartz & -17.3 & 156.8 & - & 20.4 \\
\hline LPDC C416 & $\mathrm{C}$ & 5 & & 6.6 & 13.7 & Quartz & -15.2 & 165.0 & - & 18.8 \\
\hline LPDC C416 & $\mathrm{C}$ & 5 & & 9.7 & 15.1 & Quartz & -14.0 & 166.2 & - & 17.8 \\
\hline LPDC C416 & $\mathrm{C}$ & 5 & 5 & 6.7 & 23.4 & Quartz & -13.3 & 167.2 & - & 17.2 \\
\hline LPDC C $416^{1}$ & $\mathrm{C}$ & 6 & 1 & 9.2 & 8.7 & Quartz & -13.4 & - & - & - \\
\hline LPDC C422 & $\mathrm{B}$ & 7 & & 7.3 & 8.1 & Quartz & -13.5 & - & - & 17.3 \\
\hline LPDC C422 & $\mathrm{B}$ & 7 & & 12.5 & 15.9 & Quartz & -14.4 & - & - & 18.1 \\
\hline LPDC C422 & $\mathrm{B}$ & 7 & 3 & 8.0 & 6.6 & Quartz & -14.0 & - & - & 17.7 \\
\hline LPDC C422 & B & 8 & & 9.9 & 14.3 & Quartz & -12.2 & - & - & 16.1 \\
\hline LPDC C422 & B & 8 & & 10.5 & 12.5 & Quartz & -12.1 & - & - & 16.1 \\
\hline LPDC C422 & B & 8 & 3 & 4.6 & 9.6 & Quartz & -13.0 & - & - & 16.8 \\
\hline LPDC C422 & $\mathrm{R}$ & 9 & & 10.9 & 11.3 & Quartz & -14.2 & - & - & 17.9 \\
\hline LPDC C422 & $\mathrm{R}$ & 9 & & 11.2 & 8.5 & Quartz & -13.9 & - & - & 17.7 \\
\hline LPDC C422 & $\mathrm{R}$ & 9 & 3 & 8.8 & 9.0 & Quartz & -14.4 & - & - & 18.1 \\
\hline LPDC C422 & $\mathrm{R}$ & 10 & & 6.7 & 8.8 & Quartz & -13.5 & - & - & 17.3 \\
\hline LPDC C422 & $\mathrm{R}$ & 10 & 2 & 6.5 & 8.8 & Quartz & -13.8 & - & - & 17.6 \\
\hline LPDC C43-1 & $\mathrm{D}$ & 11 & & 2.2 & 5.3 & Quartz & -12.7 & 365.3 & - & 16.6 \\
\hline LPDC C43-1 & $\mathrm{D}$ & 11 & & 2.9 & 8.9 & Quartz & - & 365.0 & - & - \\
\hline LPDC C43-1 & $\mathrm{D}$ & 11 & 3 & 4.5 & 5.1 & Quartz & - & 370.5 & - & - \\
\hline
\end{tabular}


Table 3: Microthermometry results for fluorite- and apatite-hosted fluid inclusions from Diamond Creek.

\begin{tabular}{|c|c|c|c|c|c|c|c|c|c|c|}
\hline Sample ID ${ }^{1}$ & Chip ID & FIA \# & $\begin{array}{c}\text { No. of } \\
\text { inclusions } \\
\text { in the } \\
\text { FIA }\end{array}$ & $\begin{array}{c}\text { width } \\
(\mu \mathrm{m})\end{array}$ & $\begin{array}{l}\text { length } \\
(\mu \mathrm{m})\end{array}$ & Host & $\begin{array}{c}\text { Average } \\
\operatorname{Tm}\left({ }^{\circ} \mathbf{C}\right)\end{array}$ & $\begin{array}{c}\text { Average } \\
\text { Th }\left({ }^{\circ} \mathbf{C}\right)\end{array}$ & $\begin{array}{c}\text { DM } \\
\text { Dissolve } \\
\left({ }^{\circ} \mathbf{C}\right)\end{array}$ & Salinity $^{2}$ \\
\hline LPDC C416 ${ }^{1}$ & $\mathrm{~B}$ & 1 & 1 & 17.8 & 21.3 & Fluorite & -16.8 & 176.2 & - & 20.0 \\
\hline LPDC C $416^{1}$ & B & 2 & 1 & 17.0 & 19.8 & Fluorite & -16.1 & 177.3 & - & 19.5 \\
\hline LPDC C426-1 & $\mathrm{C}$ & 3 & & 5.2 & 6.4 & Fluorite & -12.9 & 179.3 & - & 16.8 \\
\hline LPDC C426-1 & $\mathrm{C}$ & 3 & 3 & 1.7 & 2.1 & Fluorite & - & - & - & - \\
\hline LPDC C426-1 & $\mathrm{C}$ & 3 & & 3.4 & 4.0 & Fluorite & - & - & - & - \\
\hline LPDC C426-2 & B & 4 & & 3.1 & 5.3 & Fluorite & -16.6 & 259.4 & - & 19.9 \\
\hline LPDC C426-2 & B & 4 & 3 & 2.1 & 5.6 & Fluorite & -15.3 & 253.0 & - & 18.8 \\
\hline LPDC C426-2 & B & 4 & & 2.8 & 4.7 & Fluorite & -15.0 & 254.2 & - & 18.6 \\
\hline LPDC C426-2 & $\mathrm{C}$ & 5 & & 5.2 & 6.4 & Fluorite & -12.9 & 179.3 & - & 16.8 \\
\hline LPDC C426-2 & $\mathrm{C}$ & 5 & & 1.7 & 2.1 & Fluorite & - & - & - & - \\
\hline LPDC C426-2 & $\mathrm{C}$ & 5 & 6 & 3.4 & 4.0 & Fluorite & -15.1 & 189.3 & - & 18.7 \\
\hline LPDC C426-2 & $\mathrm{C}$ & 5 & 0 & 2.7 & 3.9 & Fluorite & -14.5 & 188.7 & - & 18.2 \\
\hline LPDC C426-2 & $\mathrm{C}$ & 5 & & 2.8 & 4.8 & Fluorite & -14.0 & 190.6 & - & 17.7 \\
\hline LPDC C426-2 & $\mathrm{C}$ & 5 & & 5.1 & 8.9 & Fluorite & -13.3 & 189.9 & - & 17.2 \\
\hline LPDC C426- $2^{1}$ & $\mathrm{C}$ & 6 & 1 & 5.3 & 10.8 & Fluorite & -19.7 & 206.3 & - & 22.2 \\
\hline LPDC C43-1 & A & 7 & & 5.3 & 9.1 & Fluorite & -18.8 & 184.7 & - & 21.5 \\
\hline LPDC C43-1 & $\mathrm{A}$ & 7 & 4 & 1.2 & 3.3 & Fluorite & - & 173.5 & - & - \\
\hline LPDC C43-1 & A & 7 & 4 & 1.1 & 2.6 & Fluorite & - & 174.2 & - & - \\
\hline LPDC C43-1 & A & 7 & & 3.1 & 4.8 & Fluorite & -19.1 & 177.3 & - & 21.8 \\
\hline LPDC C43- ${ }^{1}$ & A & 8 & 1 & 6.2 & 8.8 & Fluorite & -21.0 & 176.4 & - & 23.0 \\
\hline LPDC C43-1 & B & 9 & & 9.8 & 12.3 & Fluorite & -20.6 & 124.7 & - & 22.8 \\
\hline LPDC C43-1 & B & 9 & 2 & 3.0 & 5.0 & Fluorite & -18.9 & 123.0 & - & 21.6 \\
\hline LPDC C43-1 & B & 10 & & 5.3 & 5.7 & Fluorite & -17.3 & 127.8 & - & 20.4 \\
\hline LPDC C43-1 & B & 10 & 4 & 4.4 & 5.5 & Fluorite & -16.8 & 127.9 & - & 20.1 \\
\hline LPDC C43-1 & B & 10 & & 3.4 & 4.4 & Fluorite & -16.3 & 128.7 & - & 19.7 \\
\hline LPDC C43-1 & $\mathrm{B}$ & 10 & & 3.7 & 6.0 & Fluorite & -17.5 & 126.2 & - & 20.6 \\
\hline LPDC C43- $1^{1}$ & B & 11 & 1 & 3.9 & 5.8 & Apatite & -14.0 & 159.3 & - & 17.8 \\
\hline LPDC C43-1 ${ }^{1}$ & B & 12 & 1 & 9.9 & 4.4 & Fluorite & -18.2 & 119.5 & - & 21.1 \\
\hline LPDC C $43-1^{1}$ & B & 13 & 1 & 5.6 & 6.1 & Fluorite & -17.7 & 124.2 & - & 20.7 \\
\hline LPDC C43- $1^{1}$ & $\mathrm{C}$ & 14 & 1 & 19.5 & 18.3 & Fluorite & - & 123.3 & - & - \\
\hline LPDC C43- $1^{1}$ & $\mathrm{E}$ & 15 & 1 & 3.1 & 5.5 & Fluorite & - & 168.4 & - & - \\
\hline
\end{tabular}

- response not quantifiable

${ }^{1}$ Single fluid inclusion not part of a fluid inclusion as semblage (FIA)

${ }^{2}$ Salinity is wt $\%$ equivalent $\mathrm{NaCl}$ 
Table 4: Microthermometry results for quartz-hosted fluid inclusions from the Lucky Horseshoe mine in the Lemhi Pass district.

\begin{tabular}{|c|c|c|c|c|c|c|c|c|c|c|}
\hline Sample ID $^{1}$ & Chip ID & FIA \# & $\begin{array}{c}\text { No. of } \\
\text { inclusions } \\
\text { in the FIA }\end{array}$ & $\begin{array}{l}\text { width } \\
\text { ( } \boldsymbol{\mu m} \text { ) }\end{array}$ & $\begin{array}{c}\text { length } \\
(\mu \mathrm{m})\end{array}$ & Host & $\begin{array}{c}\text { Ave rage } \\
\operatorname{Tm}\left({ }^{\circ} \mathbf{C}\right)\end{array}$ & $\begin{array}{c}\text { Average } \\
\text { Th }\left({ }^{\circ} \mathrm{C}\right)\end{array}$ & $\begin{array}{c}\text { DM } \\
\text { Dissolve } \\
\left({ }^{\circ} \mathrm{C}\right)\end{array}$ & Salinity ${ }^{2}$ \\
\hline LPLH- $^{1}$ & A & 1 & 1 & 8.2 & 12.8 & Quartz & - & - & 201.6 & 32.0 \\
\hline LPLH-2 & B & 2 & & 13.4 & 16.7 & Quartz & -26.6 & - & - & 26.6 \\
\hline LPLH-2 & B & 2 & 2 & 9.7 & 12.8 & Quartz & -26.7 & - & - & 26.6 \\
\hline LPLH-2 & B & 3 & & 7.2 & 5.2 & Quartz & -33.1 & - & - & 30.7 \\
\hline LPLH-2 & B & 3 & & 10.8 & 5.9 & Quartz & -34.0 & - & - & 31.3 \\
\hline LPLH-2 & B & 3 & & 6.3 & 4.7 & Quartz & -33.7 & - & - & 31.1 \\
\hline LPLH-2 & B & 3 & & 4.8 & 15.0 & Quartz & - & - & - & - \\
\hline LPLH-2 & B & 3 & 5 & 7.2 & 15.2 & Quartz & - & - & - & - \\
\hline LPLH-2 & B & 4 & & 5.5 & 16.8 & Quartz & - & - & 200.0 & 31.9 \\
\hline LPLH-2 & B & 4 & & 8.3 & 14.0 & Quartz & - & - & 201.2 & 31.9 \\
\hline LPLH-2 & B & 4 & & 3.3 & 6.1 & Quartz & - & - & 200.0 & 31.9 \\
\hline LPLH-2 & B & 4 & 4 & 3.3 & 5.7 & Quartz & - & - & 199.8 & 31.9 \\
\hline LPLH-2 & B & 5 & & 9.1 & 8.3 & Quartz & - & - & 201.0 & 31.9 \\
\hline LPLH-2 & B & 5 & & 5.9 & 5.5 & Quartz & - & - & 200.0 & 31.9 \\
\hline LPLH-2 & B & 5 & 3 & 9.7 & 12.4 & Quartz & - & - & 200.5 & 31.9 \\
\hline LPLH-2 & B & 6 & & 9.6 & 10.1 & Quartz & - & - & 177.2 & 30.8 \\
\hline LPLH-2 & B & 6 & & 3.3 & 2.1 & Quartz & - & - & 177.2 & 30.8 \\
\hline LPLH-2 & B & 6 & 3 & 6.8 & 10.5 & Quartz & - & - & -177.2 & 30.8 \\
\hline LPLH-2 ${ }^{1}$ & B & 7 & 1 & 7.2 & 10.5 & Quartz & -26.6 & - & - & 26.6 \\
\hline LPLH-2 & C; Piece a & 8 & & 9.0 & 14.9 & Quartz & -16.2 & - & - & 19.6 \\
\hline LPLH-2 & C; Piece a & 8 & & 5.1 & 9.8 & Quartz & -16.3 & - & - & 19.7 \\
\hline LPLH-2 & C; Piece a & 8 & 3 & 7.4 & 7.4 & Quartz & -16.8 & - & - & 20.1 \\
\hline LPLH-2 & C; Piece a & 9 & & 11.6 & 21.4 & Quartz & -26.4 & - & - & 26.4 \\
\hline LPLH-2 & C; Piece a & 9 & & 19.3 & 9.8 & Quartz & -27.1 & - & - & 26.8 \\
\hline LPLH-2 & C; Piece a & 9 & 3 & 5.3 & 5.7 & Quartz & -26.9 & - & - & 26.7 \\
\hline LPLH- ${ }^{1}$ & C; Piece a & 10 & 1 & 5.4 & 7.1 & Quartz & -34.0 & - & - & 31.3 \\
\hline LPLH-2 & C; Piece a & 11 & & 8.6 & 11.5 & Quartz & -26.7 & - & - & 26.6 \\
\hline LPLH-2 & C; Piece a & 11 & & 7.8 & 8.1 & Quartz & -23.5 & - & - & 24.6 \\
\hline LPLH-2 & C; Piece a & 11 & & 4.7 & 7.8 & Quartz & -24.4 & - & - & 25.2 \\
\hline LPLH-2 & C; Piece a & 11 & & 5.1 & 8.4 & Quartz & -23.9 & - & - & 24.9 \\
\hline LPLH-2 & C; Piece a & 11 & 5 & 7.3 & 4.9 & Quartz & -23.8 & - & - & 24.8 \\
\hline LPLH-2 & C; Piece b & 12 & & 16.3 & 40.4 & Quartz & -25.6 & - & - & 25.9 \\
\hline LPLH-2 & C; Piece b & 12 & 2 & 4.8 & 5.6 & Quartz & -26.2 & - & - & 26.3 \\
\hline LPLH-2 & C; Piece b & 13 & & 11.8 & 22.3 & Quartz & -19.1 & - & - & 21.8 \\
\hline LPLH-2 & C; Piece b & 13 & 2 & 5.6 & 14.6 & Quartz & -20.2 & - & - & 22.5 \\
\hline LPLH- $^{1}$ & C; Piece b & 14 & 1 & 9.3 & 13.1 & Quartz & -24.8 & - & - & 25.4 \\
\hline LPLH-2 & C; Piece b & 15 & & 6.7 & 14.0 & Quartz & -20.1 & - & - & 22.4 \\
\hline LPLH-2 & C; Piece b & 15 & & 4.9 & 4.8 & Quartz & -20.2 & - & - & 22.5 \\
\hline LPLH-2 & C; Piece b & 15 & & 3.6 & 7.5 & Quartz & -19.4 & - & - & 22.0 \\
\hline LPLH-2 & C; Piece b & 15 & & 5.2 & 7.0 & Quartz & -20.2 & - & - & 22.5 \\
\hline LPLH-2 & C; Piece b & 15 & 5 & 5.0 & 7.6 & Quartz & -20.3 & - & - & 22.5 \\
\hline LPLH-2 & C; Piece b & 16 & & 8.4 & 11.0 & Quartz & -19.1 & - & - & 21.7 \\
\hline LPLH-2 & C; Piece b & 16 & 2 & 6.8 & 10.0 & Quartz & -19.6 & - & - & 22.1 \\
\hline LPLH-2 & E & 17 & & 10.8 & 18.7 & Quartz & - & - & 200.8 & 31.9 \\
\hline LPLH-2 & $\mathrm{E}$ & 17 & & 8.5 & 13.6 & Quartz & - & - & 183.2 & 31.1 \\
\hline LPLH-2 & $\mathrm{E}$ & 17 & & 4.3 & 6.4 & Quartz & - & - & 185.6 & 31.2 \\
\hline LPLH-2 & $\mathrm{E}$ & 17 & 4 & 11.2 & 14.1 & Quartz & - & - & 181.7 & 31.0 \\
\hline LPLH-2 & $E$ & 18 & & 8.5 & 20.0 & Quartz & - & - & 198.6 & 31.8 \\
\hline LPLH-2 & E & 18 & 2 & 8.9 & 14.7 & Quartz & - & - & 197.8 & 31.8 \\
\hline LPLH-2 & $E$ & 19 & & 10.4 & 21.6 & Quartz & - & - & 204.6 & 32.1 \\
\hline LPLH-2 & $\mathrm{E}$ & 19 & 2 & 4.4 & 11.6 & Quartz & - & - & 202.3 & 32.0 \\
\hline LPLH-2 & $\mathrm{E}$ & 20 & & 3.9 & 12.3 & Quartz & - & - & 205.3 & 32.1 \\
\hline LPLH-2 & $\mathrm{E}$ & 20 & & 4.4 & 9.7 & Quartz & - & - & 197.8 & 31.8 \\
\hline LPLH-2 & $\mathrm{E}$ & 20 & 3 & 4.7 & 6.2 & Quartz & - & - & 197.4 & 31.7 \\
\hline
\end{tabular}

- response not quantifiable

${ }^{1}$ Single fluid inclusion not part of a fluid inclusion as semblage (FIA)

${ }^{2}$ Salinity is wt \% equivalent $\mathrm{NaCl}$ 

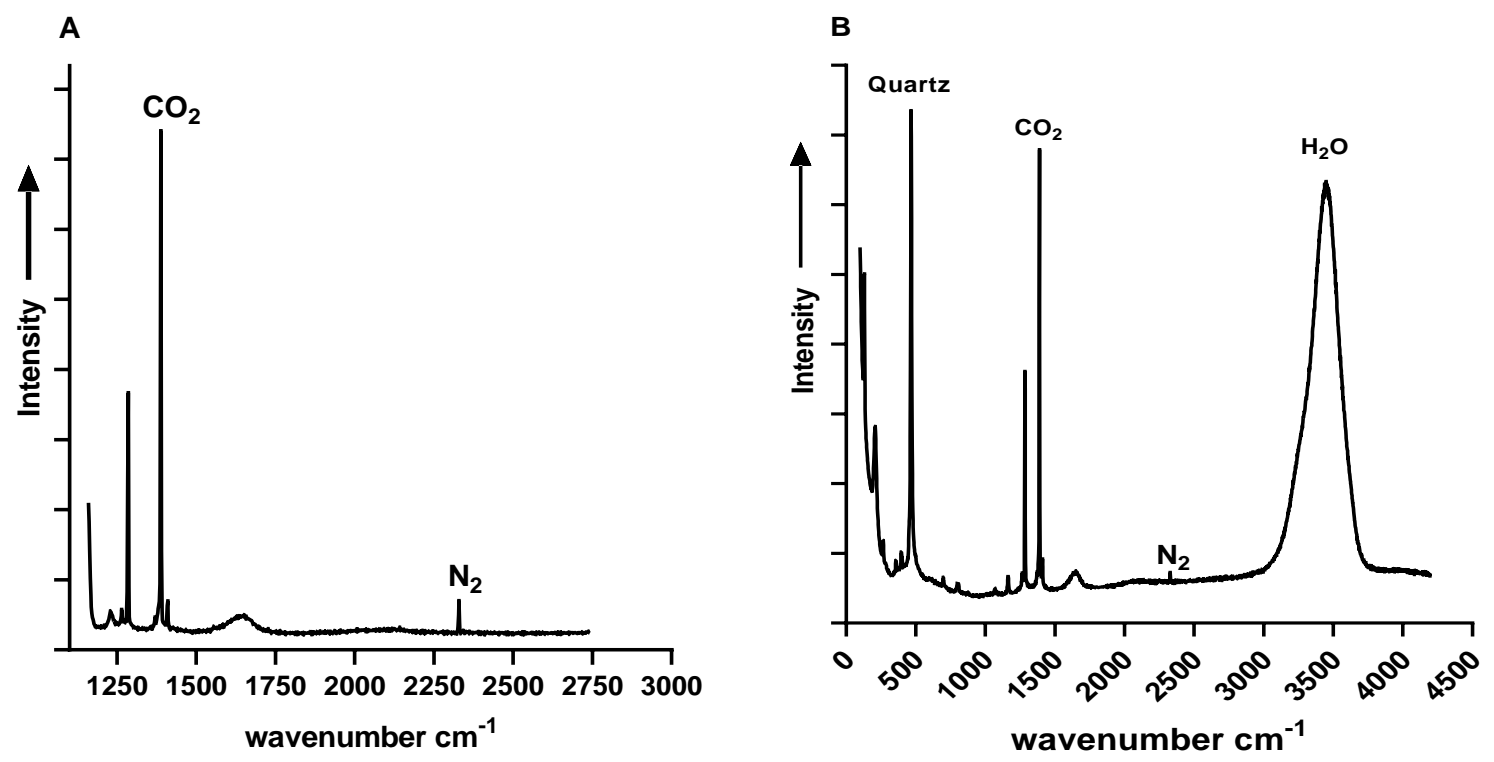

Figure 10: Representative Raman spectra for fluid inclusion vapor bubbles from (A) Diamond Creek fluorite and (B) Lemhi Pass quartz.

The raw LA-ICP-MS signals were converted to elemental concentrations using the AMS software (Mutchler et al., 2008). A fundamental task in the data reductions was to determine whether the signal for any given element originated from the fluid inclusion or from the host mineral matrix. This was accomplished by comparing each elemental spectrum to the spectrum of an element known to be in the host mineral matrix (e.g. Si for quartz and $\mathrm{Ca}$ for fluorite) and to an element known to be in the fluid inclusion (e.g. Na). Thus, elements whose spectra matched the spectrum of a host mineral element were regarded as having originated from the host mineral matrix, whereas elements whose spectra matched that of $\mathrm{Na}$ were regarded as having originated from the fluid inclusion. For example, for the fluorite-hosted fluid inclusion represented in Figure 9, $\mathrm{Pb}$ correlates better with the $\mathrm{Na}$ spectrum than with the $\mathrm{Ca}$ spectrum, indicating that the $\mathrm{Pb}$ is more likely to have originated from the fluid inclusion than from the fluorite matrix.

LA-ICP-MS analyses were also performed on the solid matrices of fluorite and quartz from Diamond Creek and quartz from Lemhi Pass. The results of these analyses 
are shown in Table 6. Quartz from both districts was found to be relatively pure $\mathrm{SiO}_{2}$, whereas fluorite from Diamond Creek contained significant concentrations of most of the targeted elements, including ppm level concentrations of Th and the REE's.

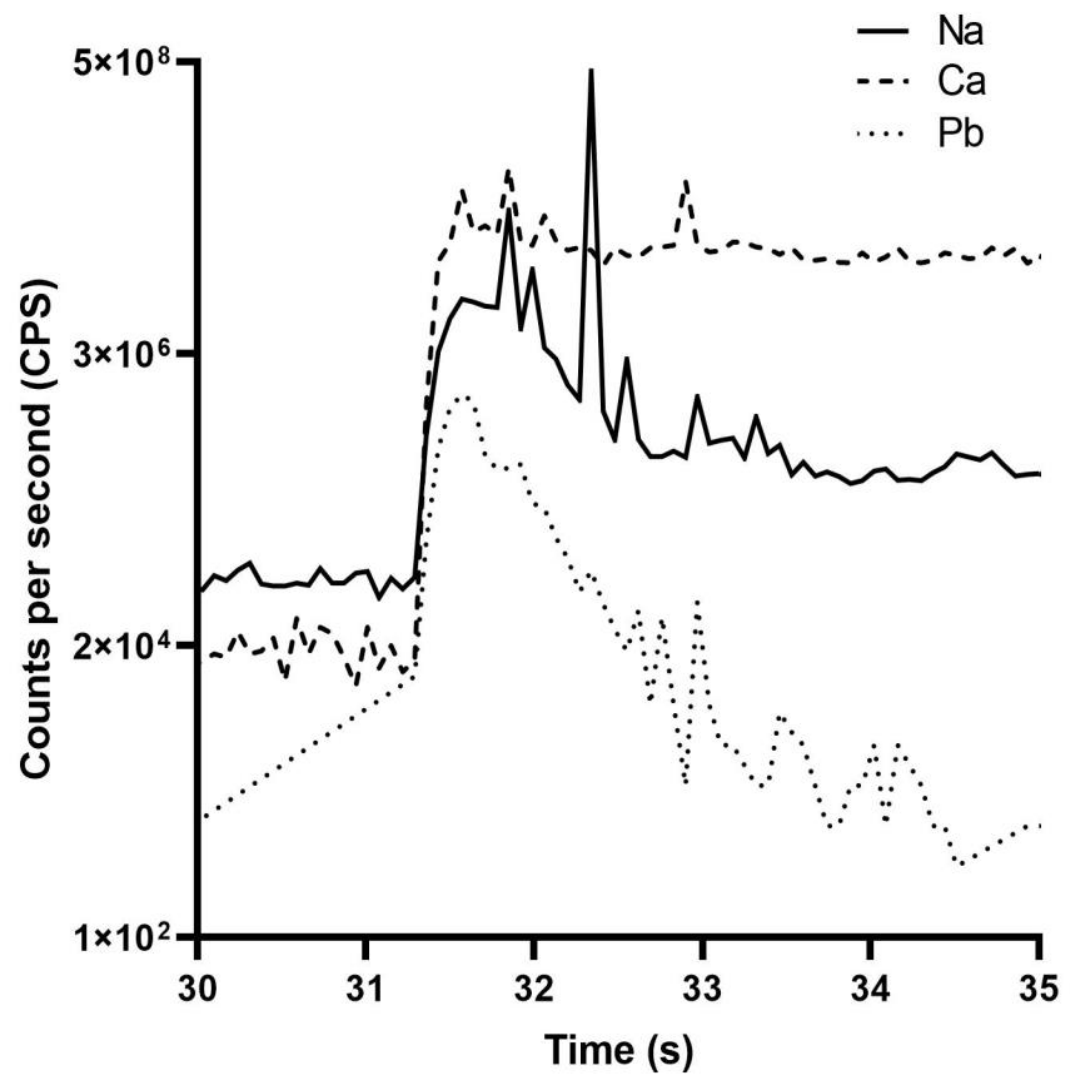

Figure 11: $\mathrm{Na}, \mathrm{Ca}$, and $\mathrm{Pb}$ spectra from a LA-ICP-MS analysis of a fluorite-hosted fluid inclusion from Diamond Creek. 

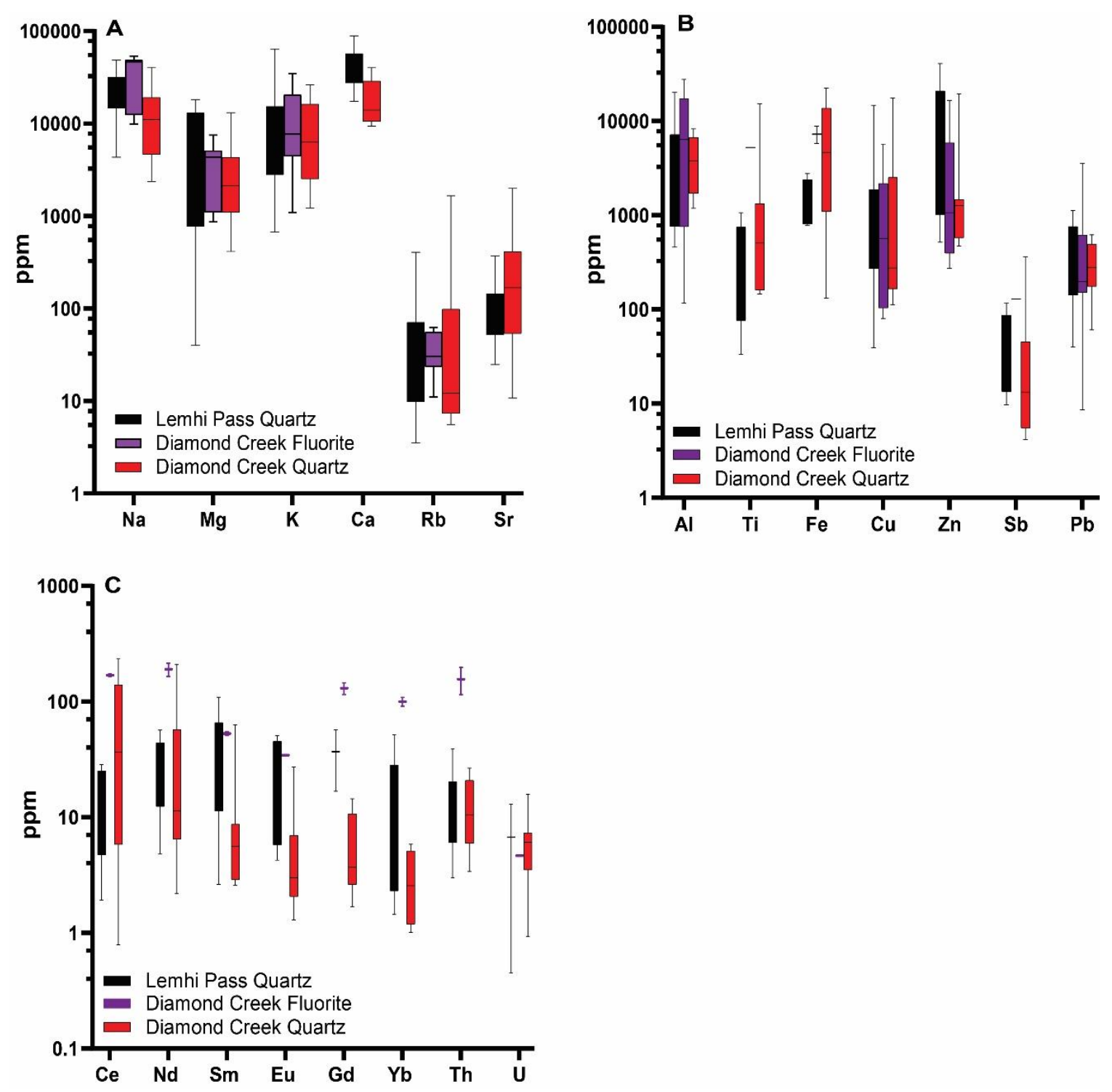

Figure 12: Box plots showing the concentrations of (A) major elements, $\mathrm{Rb}$, and $\mathrm{Sr}$, (B) base metals, (C) REE's, Th, and U in quartz- and fluorite-hosted fluid inclusions from Lemhi Pass and Diamond Creek, determined by LA-ICP-MS. The Lemhi Pass quartz is early ore-stage, the fluorite from Diamond Creek is late ore-stage, and the quartz from Diamond Creek is post ore-stage. 
Table 5: LA-ICP-MS and microthermometry results for quartz- and fluorite-hosted FIA's from Diamond Creek and Lemhi Pass.

\begin{tabular}{|c|c|c|c|c|c|c|c|c|c|c|c|c|c|c|c|c|}
\hline Sample ID ${ }^{1}$ & Chip ID & FIA\# & $\begin{array}{c}\text { No. of } \\
\text { inclusions } \\
\text { in the FIA }\end{array}$ & Host & $\begin{array}{l}\text { Average } \\
\operatorname{Tm}\left({ }^{\circ} \mathrm{C}\right)\end{array}$ & $\begin{array}{c}\text { DM } \\
\text { Dissolve } \\
\left({ }^{\circ} \mathrm{C}\right) \\
\end{array}$ & Salinity ${ }^{2}$ & $\begin{array}{c}\mathrm{Na} \\
(\mathrm{ppm})\end{array}$ & $\begin{array}{c}\mathrm{Mg} \\
(\mathrm{ppm})\end{array}$ & $\begin{array}{c}\text { Al } \\
(\mathrm{ppm})\end{array}$ & $\begin{array}{c}\mathrm{Si} \\
(\mathrm{pm})\end{array}$ & $\begin{array}{c}\mathrm{K} \\
(\mathrm{ppm}) \\
\end{array}$ & $\begin{array}{c}\mathrm{Ca} \\
(\mathrm{ppm})\end{array}$ & $\begin{array}{c}\mathrm{Ti} \\
(\mathrm{ppm})\end{array}$ & $\begin{array}{c}\mathrm{Fe} \\
(\mathrm{ppm})\end{array}$ & $\begin{array}{c}\mathrm{Cu} \\
(\mathrm{ppm})\end{array}$ \\
\hline LPDC C416 & A & 3 & 3 & Quartz & -12.5 & - & 16.4 & 16140.20 & 5745.97 & 5556.73 & - & - & 9648.09 & 15269.34 & . 131.59 & 1633.09 \\
\hline LPDC C416 & $C$ & 5 & 5 & Ouartz & 1728 & - & 20.4 & 11088.23 & 13143.41 & 4235.85 & - & 26148.47 & 14009.26 & 157.57 & 4168.85 & 112.22 \\
\hline LPDC C416 & $C$ & $J$ & $J$ & Quarte & -11.20 & - & 20.4 & 18232.77 & 1762.90 & 1936.90 & - & 16518.14 & 28599.01 & 145.62 & 1280.22 & 154.99 \\
\hline LPDC C 422 & B & 7 & 3 & Quartz & -14.1 & - & 17.9 & 20007.67 & 2930.65 & 1483.22 & - & 1217.46 & 9373.30 & 163.84 & 1021.18 & 17423.38 \\
\hline LPDC C 422 & & 8 & 3 & Ourat? & -12.4 & - & 16.3 & 4380.27 & 2488.56 & 3767.60 & - & 4118.27 & 29183.92 & 1396.04 & 11105.30 & 182.96 \\
\hline LPDC C422 & B & 8 & 3 & Q Quartz & -12.3 & - & 16.2 & 2358.16 & 2118.45 & 8247.36 & - & 6480.14 & 13108.09 & 1250.73 & 22290.62 & 275.07 \\
\hline LPDC C 422 & $\mathrm{R}$ & 9 & 3 & Quartz & -14.3 & - & 18 & 40155.52 & 426.41 & 1179.74 & - & 15295.24 & 11475.93 & 505.42 & - & 175.01 \\
\hline LPDC C422 & $\mathrm{R}$ & 10 & 2 & Ouartz & 136 & & 17.4 & 5211.45 & 414.13 & 2973.21 & - & 6106.23 & 40141.24 & 316.13 & 5159.19 & 3397.43 \\
\hline LPDC C 422 & $\mathrm{~N}$ & 10 & 2 & Quante & -15.0 & & 17.4 & 4898.68 & 1840.75 & 7818.21 & - & 1976.99 & 25494.01 & 1187.29 & 14603.12 & 477.32 \\
\hline LPLH-2 & $\mathrm{F}$ & 17 & 4 & Quartz & - & 183.8 & 31.1 & 5866.18 & 14759.87 & 11863.19 & - & 5085.31 & 56856.23 & 279.37 & - & 241.64 \\
\hline LPLH-2 & & 17 & & Quartz & - & 183.5 & 31.1 & 30719.45 & 7918.21 & - & - & 7945.91 & 34895.12 & - & - & 1834.48 \\
\hline 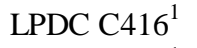 & B & 1 & 1 & Fluorite & -16.75 & - & 20 & 12382.95 & 1090.56 & 116.36 & 17166.98 & 7804.33 & - & - & 5726.99 & 5691.77 \\
\hline LPDC C416 & B & 2 & 1 & Fluorite & -16.17 & - & 19.6 & 22324.24 & 863.92 & - & - & 5277.36 & - & 5224.97 & 8776.27 & - \\
\hline LPDC C43-1 & A & 7 & 4 & Fluorite & -18.9 & - & 21.6 & 48819.77 & 4986.48 & 13941.61 & - & 1092.65 & - & - & - & 79.88 \\
\hline LPDC C $43-1^{1}$ & A & 8 & 1 & Fluorite & -21 & - & 23 & 46527.48 & 7483.63 & 7941.12 & - & 4397.35 & - & - & - & 111.18 \\
\hline LPDC C43-1 & B & 9 & 2 & Fluorite & -19.8 & - & 22.2 & 53552.65 & 4343.33 & 4773.71 & - & 20518.58 & - & - & - & 329.26 \\
\hline LPDC C $43-1^{1}$ & B & 12 & 1 & Fluorite & -18.2 & - & 21.1 & 48329.08 & 3280.49 & 969.14 & - & 34733.36 & - & - & - & 792.31 \\
\hline LPDC C $43-1^{1}$ & B & 13 & 1 & Fluorite & -17.5 & - & - & 9887.14 & 5123.21 & 27672.58 & - & 7696.59 & - & - & - & 1006.90 \\
\hline
\end{tabular}

- response not quantifiable

${ }^{1}$ Single fluid inclusion not part of a fluid inclusion as semblage (FIA)

${ }^{2}$ Salinity is wt $\%$ equivalent $\mathrm{NaCl}$ 
Table 5: (cont.)

\begin{tabular}{|c|c|c|c|c|c|c|c|c|c|c|c|c|c|c|c|c|c|c|c|c|}
\hline Sample ID ${ }^{1}$ & Chip ID & FIA\# & $\begin{array}{c}\text { No. of } \\
\text { inclusions } \\
\text { in the FIA }\end{array}$ & Host & $\begin{array}{l}\text { Average } \\
\operatorname{Tm}\left({ }^{\circ} \mathrm{C}\right)\end{array}$ & $\begin{array}{c}\text { DM } \\
\text { Dissolve } \\
\left({ }^{\circ} \mathrm{C}\right) \\
\end{array}$ & Salinity ${ }^{2}$ & $\begin{array}{c}\mathrm{Zn} \\
(\mathrm{ppm})\end{array}$ & $\begin{array}{c}\mathbf{R b} \\
(\mathrm{ppm})\end{array}$ & $\begin{array}{c}\mathrm{Sr} \\
(\mathrm{ppm})\end{array}$ & $\begin{array}{c}\text { Sb } \\
(\mathrm{ppm})\end{array}$ & $\begin{array}{c}\mathrm{Ce} \\
(\mathrm{ppm})\end{array}$ & $\begin{array}{c}\mathrm{Nd} \\
(\mathrm{ppm})\end{array}$ & $\begin{array}{c}\mathrm{Sm} \\
(\mathrm{ppm})\end{array}$ & $\begin{array}{c}\mathrm{Eu} \\
(\mathrm{ppm})\end{array}$ & $\begin{array}{c}\text { Gd } \\
(\mathrm{ppm})\end{array}$ & $\begin{array}{c}\mathrm{Yb} \\
(\mathrm{ppm})\end{array}$ & $\begin{array}{c}\mathrm{Pb} \\
\text { (ppm) }\end{array}$ & $\begin{array}{c}\text { Th } \\
\text { (ppm) }\end{array}$ & $\begin{array}{c}U \\
\text { (ppm) }\end{array}$ \\
\hline LPDC C416 & A & 3 & 3 & Quartz & -12.5 & - & 16.4 & 1265.93 & 1655.04 & 49.70 & 360.68 & 133.49 & 87.83 & 8.72 & 4.48 & 14.42 & 5.85 & 517.97 & 20.35 & 5.15 \\
\hline LPDC C416 & \multirow{2}{*}{$\mathrm{C}$} & \multirow{2}{*}{5} & \multirow{2}{*}{5} & \multirow{2}{*}{ Quartz } & \multirow{2}{*}{-17.28} & - & 20.4 & 1590.08 & 124.75 & 410.15 & 4.75 & 0.79 & 4.56 & 5.81 & - & 3.55 & - & 279.90 & 4.41 & 7.32 \\
\hline LPDC C416 & & & & & & - & 20.4 & 558.13 & 5.57 & 57.49 & 7.83 & 233.30 & 8.32 & - & 2.06 & - & 1.01 & 60.59 & 7.45 & 6.08 \\
\hline LPDC C422 & B & 7 & 3 & Quartz & -14.1 & - & 17.9 & 19408.89 & 11.09 & 10.82 & 17.25 & 4.86 & 11.76 & 62.86 & - & - & 1.37 & 152.79 & 10.52 & 6.82 \\
\hline LPDC C 422 & \multirow{2}{*}{ B } & \multirow{2}{*}{8} & \multirow{2}{*}{3} & \multirow{2}{*}{ Quartz } & -12.4 & - & 16.3 & 1332.11 & 48.53 & 177.29 & - & 51.89 & 208.03 & - & 27.07 & - & - & 236.11 & 9.90 & 15.81 \\
\hline LPDC C422 & & & & & -12.3 & - & 16.2 & 682.82 & 7.76 & 167.96 & 4.17 & 36.42 & 11.38 & 2.59 & 3.00 & 3.68 & 2.56 & 463.48 & 21.33 & 0.93 \\
\hline LPDC C422 & $\mathrm{R}$ & 9 & 3 & Quartz & -14.3 & - & 18 & 1346.31 & 72.91 & 1994.19 & 52.37 & 6.80 & 9.09 & 4.06 & 2.95 & - & - & 620.42 & 3.39 & - \\
\hline LPDC C422 & \multirow{2}{*}{$\mathrm{R}$} & \multirow{2}{*}{10} & \multirow{2}{*}{2} & \multirow{2}{*}{ Quartz } & \multirow{2}{*}{-13.6} & \multirow[b]{2}{*}{ - } & 17.4 & 472.33 & 12.12 & 87.63 & 23.94 & 146.16 & 2.20 & 5.61 & 1.29 & 1.68 & 4.41 & 198.73 & 26.57 & 3.50 \\
\hline LPDC C422 & & & & & & & 17.4 & 595.16 & 6.93 & 413.81 & 9.27 & 19.00 & 27.08 & 2.90 & 6.97 & 7.00 & - & 415.91 & 17.96 & - \\
\hline LPLH-2 & \multirow{2}{*}{ E } & \multirow{2}{*}{17} & \multirow{2}{*}{4} & Quartz & - & 183.8 & 31.1 & 1347.73 & - & 106.63 & - & 28.01 & 56.55 & - & - & - & - & 166.89 & - & - \\
\hline LPLH-2 & & & & Quartz & - & 183.5 & 31.1 & 40557.94 & 68.98 & 51.93 & - & 28.49 & 4.80 & 108.93 & 10.28 & - & 4.73 & 774.96 & 17.95 & - \\
\hline LPDC C $416^{1}$ & B & 1 & 1 & Fluorite & -16.75 & - & 20 & 272.97 & 31.13 & - & 129.16 & 173.85 & 214.86 & 54.80 & 33.92 & 115.49 & 91.00 & 154.51 & 197.18 & - \\
\hline LPDC C $416^{1}$ & B & 2 & 1 & Fluorite & -16.17 & - & 19.6 & - & 30.48 & - & - & 163.67 & 164.65 & 50.69 & 34.79 & 145.73 & 108.33 & 8.55 & 114.91 & - \\
\hline LPDC C43-1 & A & 7 & 4 & Fluorite & -18.9 & - & 21.6 & 436.60 & 24.12 & - & - & - & - & - & - & - & - & 151.53 & - & - \\
\hline $\mathrm{LPDC} \mathrm{C} 43-1^{1}$ & A & 8 & 1 & Fluorite & -21 & - & 23 & 16515.21 & 62.62 & - & - & - & - & - & - & - & - & 243.74 & - & 4.66 \\
\hline LPDC C43-1 & B & 9 & 2 & Fluorite & -19.8 & - & 22.2 & 2322.04 & 23.49 & - & - & - & - & - & - & - & - & 620.01 & - & - \\
\hline LPDC C43- ${ }^{1}$ & B & 12 & 1 & Fluorite & -18.2 & - & 21.1 & 1108.25 & 55.73 & - & - & - & - & - & - & - & - & 196.70 & - & - \\
\hline LPDC C43- ${ }^{1}$ & $\mathrm{~B}$ & 13 & 1 & Fluorite & -17.5 & - & - & 1026.39 & 11.05 & - & - & - & - & - & - & - & - & 3540.86 & - & - \\
\hline
\end{tabular}

- response not quantifiable
${ }^{1}$ Single fluid inclusion not part of a fluid inclusion assemblage (FIA)

${ }^{2}$ Salinity is wt $\%$ equivalent $\mathrm{NaCl}$ 
Table 6: Elemental compositions of fluorite and quartz mineral matrix from Lemhi Pass and Diamond Creek determined by LA-ICP-MS.

\begin{tabular}{|c|c|c|c|c|c|c|c|c|c|c|c|c|c|c|c|c|c|c|c|c|c|c|c|c|}
\hline Sample ID & Chip ID & Host & $\begin{array}{c}\mathrm{Na} \\
(\mathrm{ppm}) \\
\end{array}$ & $\begin{array}{c}\mathrm{Mg} \\
(\mathrm{ppm}) \\
\end{array}$ & $\begin{array}{r}\mathrm{Al} \\
(\mathrm{ppm})\end{array}$ & $\begin{array}{c}\mathrm{Si} \\
(\mathrm{ppm}) \\
\end{array}$ & $\begin{array}{c}\mathrm{K} \\
(\mathrm{ppm}) \\
\end{array}$ & $\begin{array}{c}\mathrm{Ca} \\
(\mathrm{ppm}) \\
\end{array}$ & $\begin{array}{c}\mathrm{Ti} \\
(\mathrm{ppm})\end{array}$ & $\begin{array}{c}\mathrm{Fe} \\
(\mathrm{ppm})\end{array}$ & $\begin{array}{c}\mathrm{Cu} \\
(\mathrm{ppm})\end{array}$ & $\begin{array}{c}\mathbf{Z n} \\
(\mathrm{ppm}) \\
\end{array}$ & $\begin{array}{c}\mathbf{R b} \\
(\mathrm{ppm}) \\
\end{array}$ & $\begin{array}{c}\begin{array}{c}\mathrm{Sr} \\
(\mathrm{ppm})\end{array} \\
\end{array}$ & $\begin{array}{c}\text { Sb } \\
(\mathrm{ppm})\end{array}$ & $\begin{array}{c}\mathrm{Ce} \\
(\mathrm{ppm})\end{array}$ & $\begin{array}{c}\text { Nd } \\
(\mathrm{ppm})\end{array}$ & $\begin{array}{c}\text { Sm } \\
(\mathrm{ppm})\end{array}$ & $\begin{array}{c}\begin{array}{c}\text { Eu } \\
(\mathrm{ppm})\end{array} \\
\end{array}$ & $\begin{array}{c}\text { Gd } \\
(\mathrm{ppm})\end{array}$ & $\begin{array}{c}\mathbf{Y b} \\
(\mathrm{ppm})\end{array}$ & $\begin{array}{c}\mathrm{Pb} \\
(\mathrm{ppm})\end{array}$ & $\begin{array}{c}\text { Th } \\
(\mathrm{ppm})\end{array}$ & $\begin{array}{c}\mathrm{U} \\
(\mathrm{ppm})\end{array}$ \\
\hline LPDC C43-1 & B & Fluorite & 123.60 & 34.13 & - & - & - & $\begin{array}{l}507143.65 \\
\end{array}$ & 211.14 & $\begin{array}{l}304.72 \\
\end{array}$ & - & 2.96 & - & 7400.60 & - & 1.14 & 2.27 & 3.05 & 2.55 & 16.45 & 18.47 & 0.48 & 0.24 & - \\
\hline LPDC C43-1 & B & Fluorite & 146.56 & 33.46 & - & - & 29.70 & 507239.97 & 230.53 & 305.98 & 0.22 & 2.36 & 0.36 & 7170.27 & - & 1.72 & 3.04 & 4.10 & 2.86 & 19.48 & 17.54 & - & 1.10 & 0.03 \\
\hline LPDC C43-1 & D & Quartz & - & 283.38 & 921.08 & 461956.64 & - & - & - & - & - & 220.40 & - & - & - & - & - & - & - & 12.34 & - & 126.93 & - & 5.84 \\
\hline LPDC C43-1 & D & Quartz & - & - & - & 466857.24 & - & - & - & - & - & - & 16.85 & - & - & - & - & - & - & - & - & - & - & - \\
\hline LPDC C410 & C & Quartz & 48.77 & 32.29 & 84.75 & 466802.67 & - & 685.62 & - & - & 3.76 & 12.37 & - & - & - & - & - & - & - & - & - & 3.68 & - & 0.36 \\
\hline LPDC C410 & C & Quartz & - & 45.76 & 138.05 & 467082.77 & & & - & - & - & - & - & - & - & - & - & - & - & - & 16.69 & - & - & - \\
\hline LPDC C416 & B & Fluorite & 111.48 & 33436.54 & 15808.63 & & 16900.94 & 416697.48 & & 9882.63 & 0.89 & 19.35 & 153.23 & 5132.28 & & 5.01 & 7.90 & 5.78 & 3.31 & 15.29 & 5.04 & 0.42 & 1.07 & 0.28 \\
\hline LPDC C416 & B & Fluorite & 749.82 & 37.33 & & - & 314.01 & 508562.39 & 262.33 & 290.51 & 0.33 & 4.64 & 2.83 & 4286.20 & - & 2.17 & 2.14 & 1.76 & 1.17 & 6.56 & 4.25 & 2.36 & 1.28 & - \\
\hline LPDC C426 & C & Fhorite & 117.73 & 28.08 & 23.34 & & 31.88 & 506079.20 & & 924.45 & 1.47 & 1.17 & 0.12 & 6697.58 & & 2.64 & 3.77 & 2.30 & 1.33 & 7.33 & 2.88 & 1.77 & 1.83 & - \\
\hline LPDC C422 & B & Quartz & - & - & 7.47 & 467027.98 & - & - & - & - & - & - & - & - & - & - & - & - & - & - & - & - & - & 0.26 \\
\hline LPLH-2 & E & Quartz & - & 1.73 & 6.94 & 467139.70 & - & - & - & - & - & - & - & 0.49 & - & - & - & - & - & - & - & - & - & - \\
\hline LPLH-2 & Chip C;Piece A & Quartz & - & - & 9.87 & 466964.59 & - & - & - & - & - & - & - & - & - & - & - & - & - & - & - & 5.87 & - & - \\
\hline LPLH-2 & Chip C;Piece B & Quartz & 35.64 & - & - & 466959.29 & - & - & - & - & 7.54 & - & - & - & - & - & - & - & - & - & - & - & - & - \\
\hline LPLH-2 & Chip C;Piece B & Quartz & - & - & - & 467221.73 & - & - & - & - & - & - & - & - & - & - & - & - & - & - & - & - & - & - \\
\hline LPLH-2 & Chip C;Piece B & Quartz & 11.67 & 1.20 & 11.67 & 467181.71 & - & 341.46 & 5.45 & - & 0.81 & 5.02 & - & - & - & - & - & - & - & - & - & 0.23 & - & - \\
\hline
\end{tabular}

- response not quantifiable

'Single fluid inclusion not part of a fluid inclusion assemblage (FIA)

${ }^{2}$ Salinity is wt \% equivalent $\mathrm{NaCl}$ 
Figure 12 contains box plots showing the concentrations of elements measured by LAICP-MS in fluid inclusions hosted by quartz and fluorite from Lemhi Pass and Diamond Creek. Fluid inclusions hosted by all three minerals are similar in some respects, such as their concentrations of the major elements ( $\mathrm{Na}, \mathrm{Mg}, \mathrm{K}, \mathrm{Ca}$ ), $\mathrm{Rb}, \mathrm{Sr}, \mathrm{Al}, \mathrm{Cu}$, and $\mathrm{Pb}$. Fluid inclusions in all three minerals have Th and REE concentrations on the order of 1's to 100's of ppm. However, Th and the REE's concentrations in fluorite-hosted fluid inclusions are consistently high compared to these elements' concentrations in quartz-hosted fluid inclusions.

A fundamental question about the origin of the Lemhi Pass and Diamond Creek Th-REE deposits is what kind of crustal fluid formed the deposits (Gibson, 1998; Gillerman, 2008). One option is that the deposits formed from magmatic hydrothermal fluids, in particular, fluids exsolved from carbonatite, as carbonatites tend to be enriched in Th and REE's relative to other kinds of rocks (Jones et al., 2013). In the west-central part of the Lemhi Pass district, a small outcrop of igneous rock containing coarse-grained apatite, calcite, dolomite, biotite, chlorite, and magnetite has been classified as carbonatite (Staatz, 1979; Gibson 1998; Gillerman, 2008), and is closely associated with a mafic igneous rock containing coarse-grained amphibole, pyroxene, and biotite, with what appears to be later calcite alteration (Fig. 13). A second option is that the ThREE deposits were precipitated from sedimentary brines that formed sediment-hosted base metal mineralization (sedimentary exhalative [SEDEX] and Mississippi Valley-type [MVT]) in the region during the middle Paleozoic. These brines would have acquired their Th and REE content by leaching it from the rocks through which they circulated. 


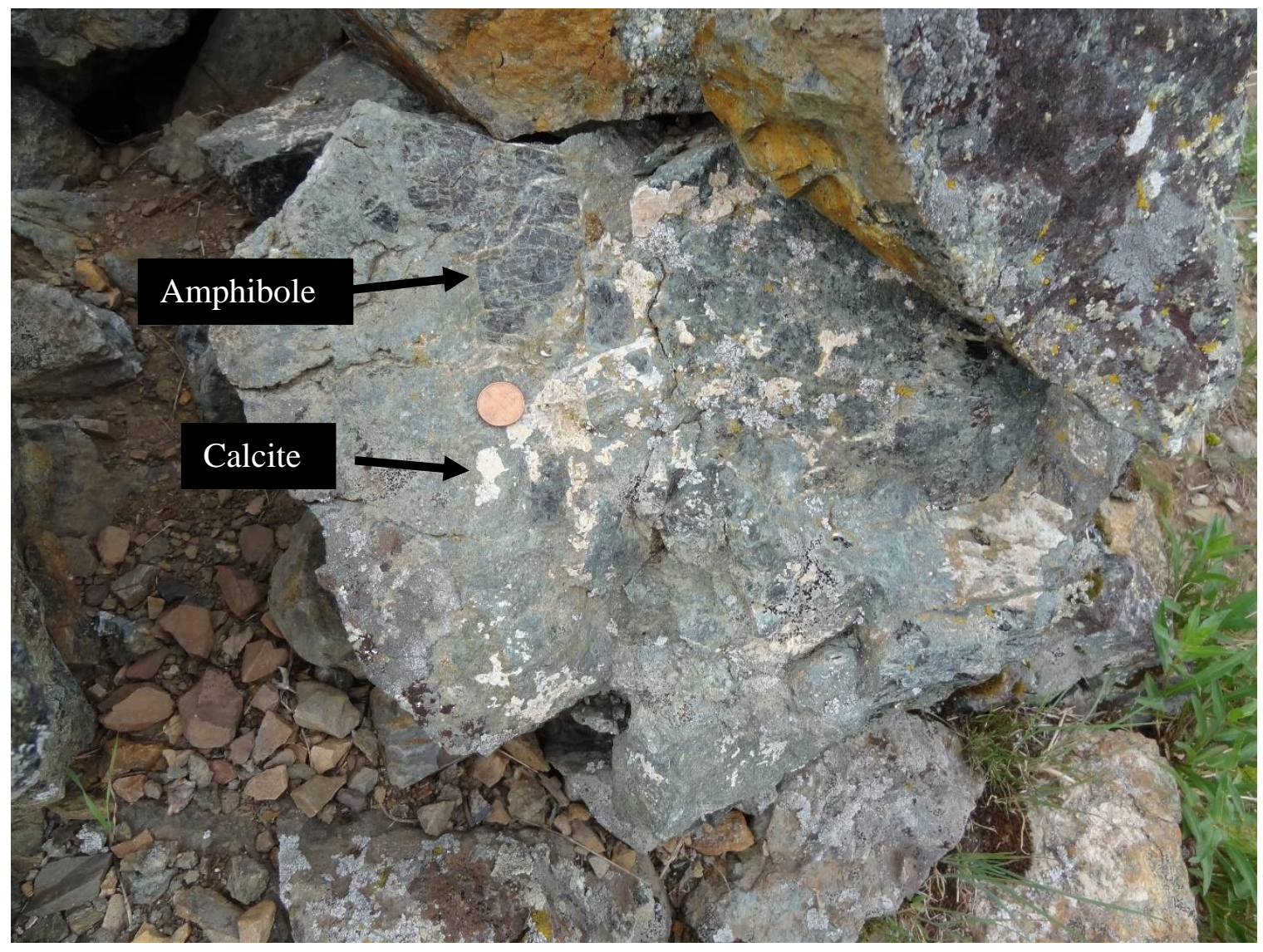

Figure 13: Mafic igneous rock in the Lemhi Pass district, reported to be associated with carbonatite (Staatz, 1979; Gibson, 1998; Gillerman, 2008). The light colored mineral is calcite, probably a secondary alteration product. Large, dark crystals are xenocrysts of amphibole.

Figure 14 addresses the question of what type of crustal fluid formed the Lemhi Pass and Diamond Creek Th-REE deposits. The figure compares the atomic ratios of various elements to $\mathrm{Na}$ in fluid inclusions determined in the present study with those in metamorphic fluids, geothermal fluids, magmatic fluids, $\mathrm{CO}_{2}-\mathrm{H}_{2} \mathrm{O}$ fluids, shield brines, and sedimentary formation waters compiled by Yardley (2005). The Lemhi Pass and Diamond Creek fluid inclusion data do not exactly match any of Yardley's (2005) fluid types, but overall overlap the magmatic fluid compositions the most. The Lemhi Pass and Diamond Creek fluid inclusions consistently have higher element:Na ratios than sedimentary brines. 
If Lemhi Pass and Diamond Creek fluid inclusions resemble magmatic fluids in chemical composition, then a further question is whether the fluid inclusions resemble magmatic fluids exsolved from carbonatite specifically. This idea was tested in Figure 15, in which the elemental compositions of fluid inclusions from Lemhi Pass and Diamond Creek are compared to those of fluid inclusions hosted in hydrothermal quartz and fluorite associated with the Karasug and Ulatay carbonatites, respectively, from the Tuva region in south-central Russia near the border with Mongolia (Prokopyev et al., 2012). In general, fluid inclusions from the Tuva carbonatites are much more saline than those from Lemhi Pass and Diamond Creek. Salinities in the Tuva carbonatites range from 70 to $85 \mathrm{NaCl}$ wt. \% equiv. during the early stages of mineralization, to 25 to $40 \mathrm{NaCl}$ wt. \% equiv. during the latter stages of mineralization. In contrast, salinities in Lemhi Pass and Diamond Creek range from about 16 to $32 \mathrm{NaCl}$ wt. \% equiv. The higher salinities of the Tuva carbonatite fluid inclusions probably explain their greater concentrations of most individual elements compared to Lemhi Pass and Diamond Creek. One big difference between the Tuva carbonatite fluid inclusions and the Lemhi Pass and Diamond Creek fluid inclusions is that the Tuva fluid inclusions have much higher $\mathrm{Na} / \mathrm{Ca}$ ratios. Lemhi Pass and Diamond Creek fluid inclusions have base metal and REE concentrations that for the most part lie within or strongly overlap the concentration ranges of these elements in the Tuva carbonatite fluid inclusions.

A further test of a genetic link of the Lemhi Pass and Diamond Creek Th-REE mineralization to carbonatites is shown in Figure 16. Here, REE concentrations in the matrix of fluorite from Diamond Creek are compared to those in the matrix of fluorite from the Illinois-Kentucky district, a continental rift-related hybrid MVT and magmatic hydrothermal ore district with an inferred carbonatite association (Denny, 2017). Carbonatites tend to be enriched in the middle REE's, creating a convex upward pattern in a plot of REE concentration versus REE atomic number. REE concentration in fluorite from Diamond Creek show relative enrichments in the middle 
REE's but not strong corresponding decreases in the concentrations of the heavy REE's. Thus, fluid inclusion and fluorite matrix compositions from Lemhi Pass and Diamond Creek do not have a clear-cut carbonatite fingerprint, though the possibility of a carbonatite component in a mixture with components from other sources cannot be ruled out.

Because of the possible importance of sedimentary brines in the formation of the Lemhi Pass and Diamond Creek Th-REE deposits (Gillerman, 2008), Figure 17 was produced to provide another comparison between the compositions of Lemhi Pass and Diamond Creek fluid inclusions and sedimentary brines. Figure 17 shows that Lemhi Pass and Diamond Creek fluid inclusion compositions generally lie within the compositional fields of sedimentary brines. Exceptions are that Lemhi Pass and Diamond Creek fluid inclusions tend to be enriched in $\mathrm{K}$ and depleted in $\mathrm{Na}$ relative to sedimentary brines. The enrichment in $\mathrm{K}$ relative to typical sedimentary brines is a common feature of MVT ore fluids, which are regarded as sedimentary brines (Sverjensky, 1984). Thus, the K enrichment in Lemhi Pass and Diamond Creek fluid inclusions does not rule out the possibility of a sedimentary brine component in these districts' ore fluids. Interestingly, the relatively low Na concentrations of Lemhi Pass and Diamond Creek fluid inclusions systematically elevates all of their element: $\mathrm{Na}$ atomic ratios in Figure 14, leading to a poor fit between most of the Lemhi Pass and Diamond Creek element:Na ratios and those of sedimentary brines. Thus, Figure 17 suggests that the fit between the compositions of Lemhi Pass and Diamond Creek fluid inclusions and sedimentary brines may be better than indicated by Figure 14 .

Further insights into the nature of the fluids that formed the Lemhi Pass and Diamond Creek Th-REE deposits can be gained from Figure 18. The figure shows fields in salinity-temperature space occupied by sedimentary basinal brines, epithermal fluids, metamorphic fluids, primary magmatic fluids, secondary magmatic fluids, and magmatic fluids mixed with meteoric fluids from Sharma and Srivastava (2015). The Lemhi Pass and Diamond Creek fluid inclusion data obtained in the present study for the most part plot in the sedimentary basinal brine field, 
though a few fluid inclusions plot in the metamorphic fluid and magmatic-meteoric fluid mixture fields. Because the Lemhi Pass and Diamond Creek fluid inclusion salinities also lie within the range of salinities of secondary magmatic fluids, the Lemhi Pass and Diamond Creek fluid inclusions could represent a secondary magmatic fluid that has cooled. Moreover, if the 350 to $525^{\circ} \mathrm{C}$ ore formation temperature determined by Gibson (1998) from monazite geothermometry is cor-

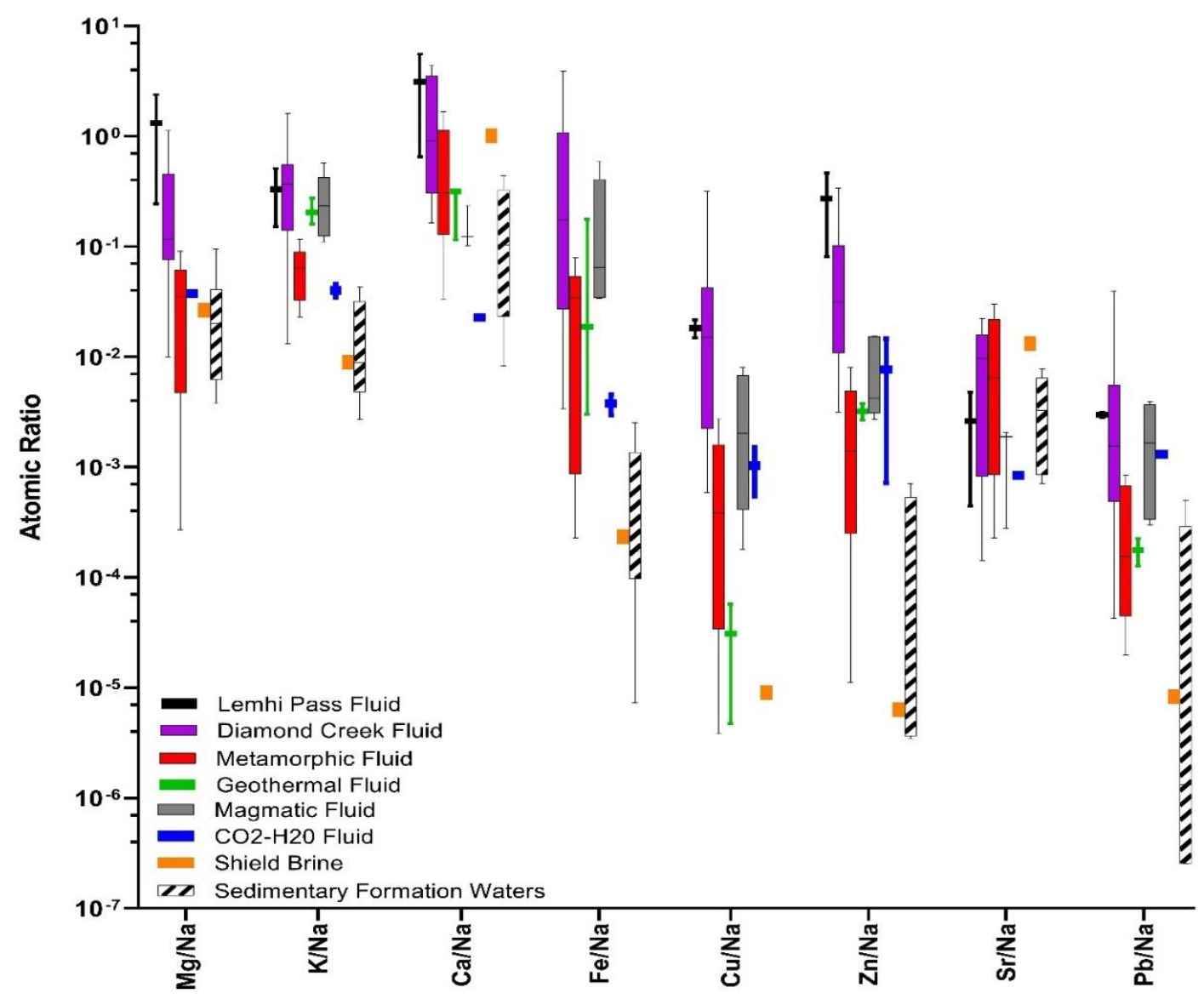

Figure 14: Boxplot comparing the element:Na atomic ratios of fluid inclusions in quartz from Lemhi Pass and fluorite from Diamond Creek with those in various crustal fluid types compiled by Yardley (2005).

rect, then the Lemhi Pass and Diamond Creek ore fluids would lie well within the magmatic-meteoric fluid mixture field. 

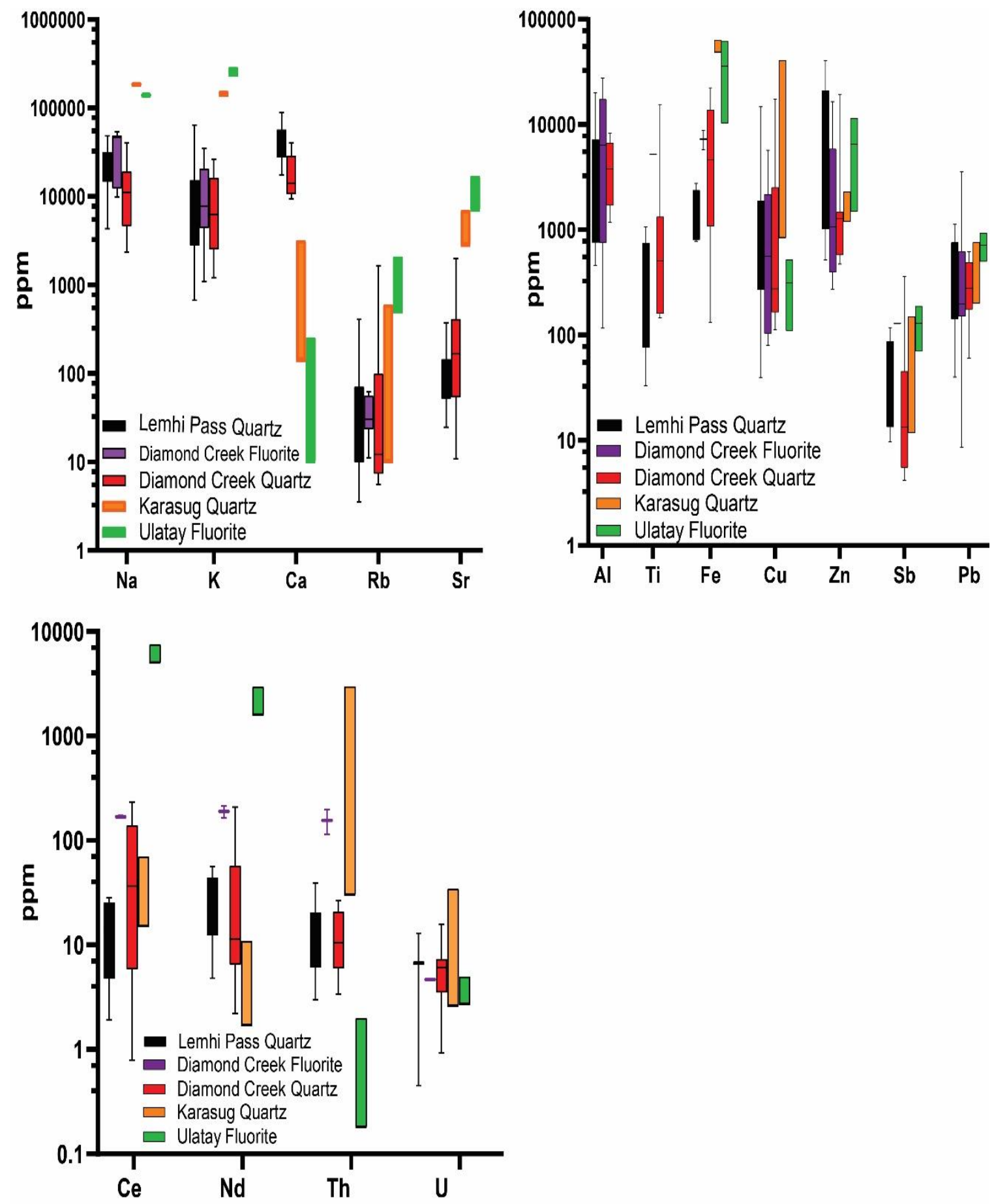

Figure 15: Comparison of the compositions of fluid inclusions from Lemhi Pass and Diamond Creek to fluid inclusions in hydrothermal quartz and fluorite associated with the Karasug and Ulatay carbonatites, respectively, from the Tuva region in south-central Russia (Prokopyev et al., 2012). 


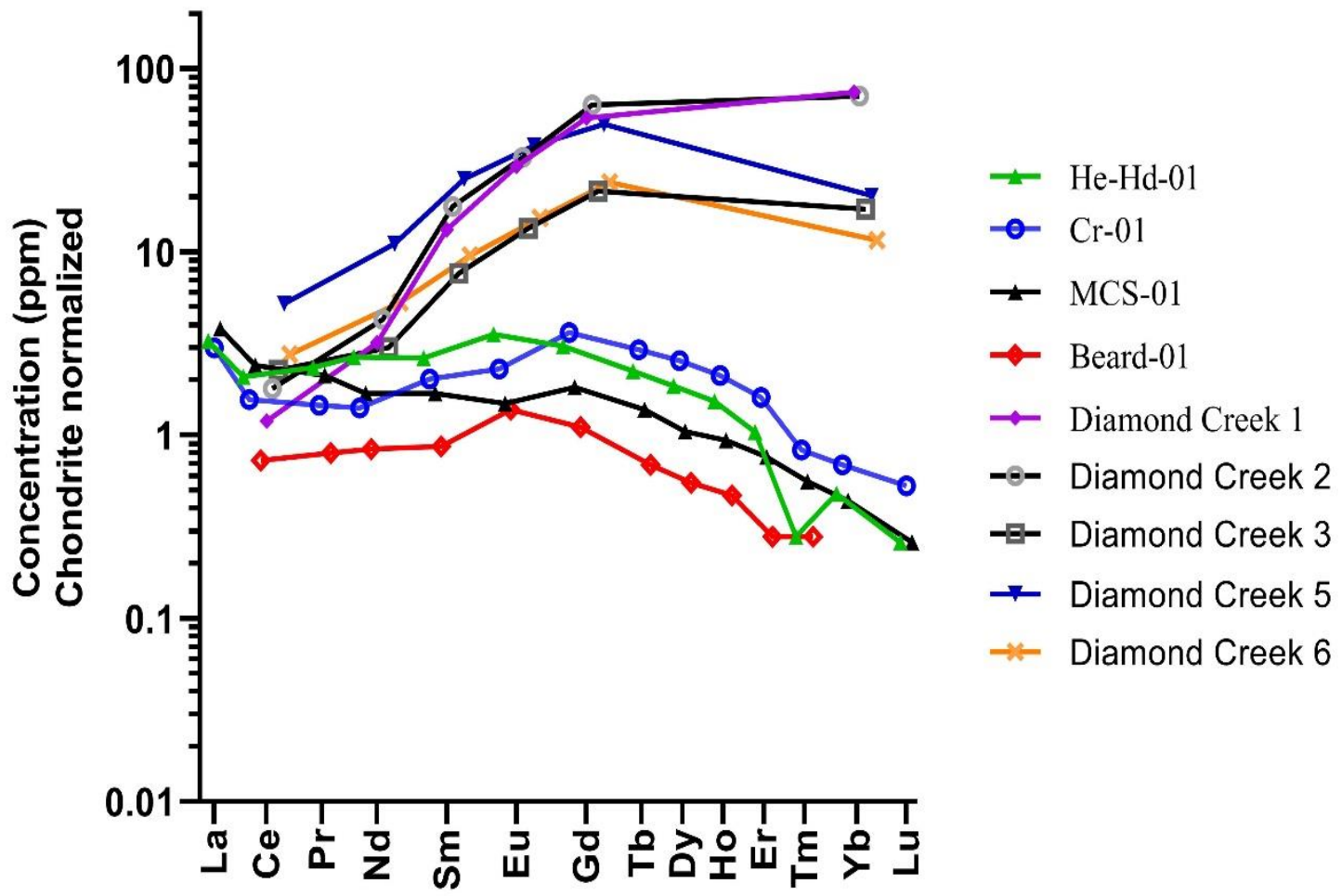

Figure 16: Comparison of REE concentrations in fluorite from Diamond Creek with those in fluorite from the Illinois-Kentucky MVT district. Illinois-Kentucky data are from Denny (2017). All REE concentrations were chondrite normalized using Taylor and McLennan (1985). 

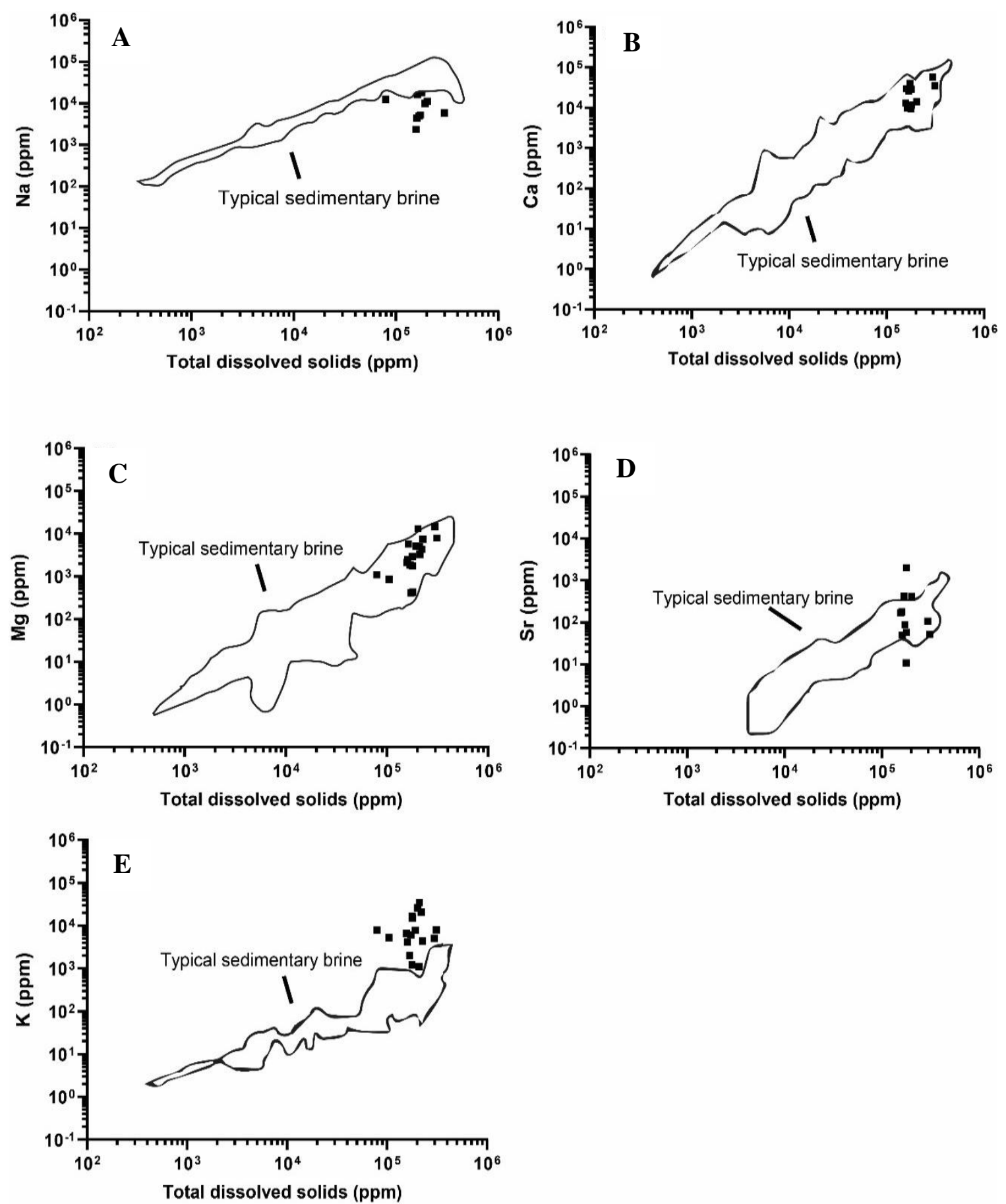

Figure 17: Plots showing the concentrations of (A) $\mathrm{Na}$, (B) $\mathrm{Ca}$, (C) $\mathrm{Mg}$, (D) $\mathrm{Sr}$, and (E) $\mathrm{K}$ versus total dissolved solids content in fluid inclusions from Lemhi Pass and Diamond Creek relative to the fields of typical sedimentary brine compositions (Hanor, 1996). 


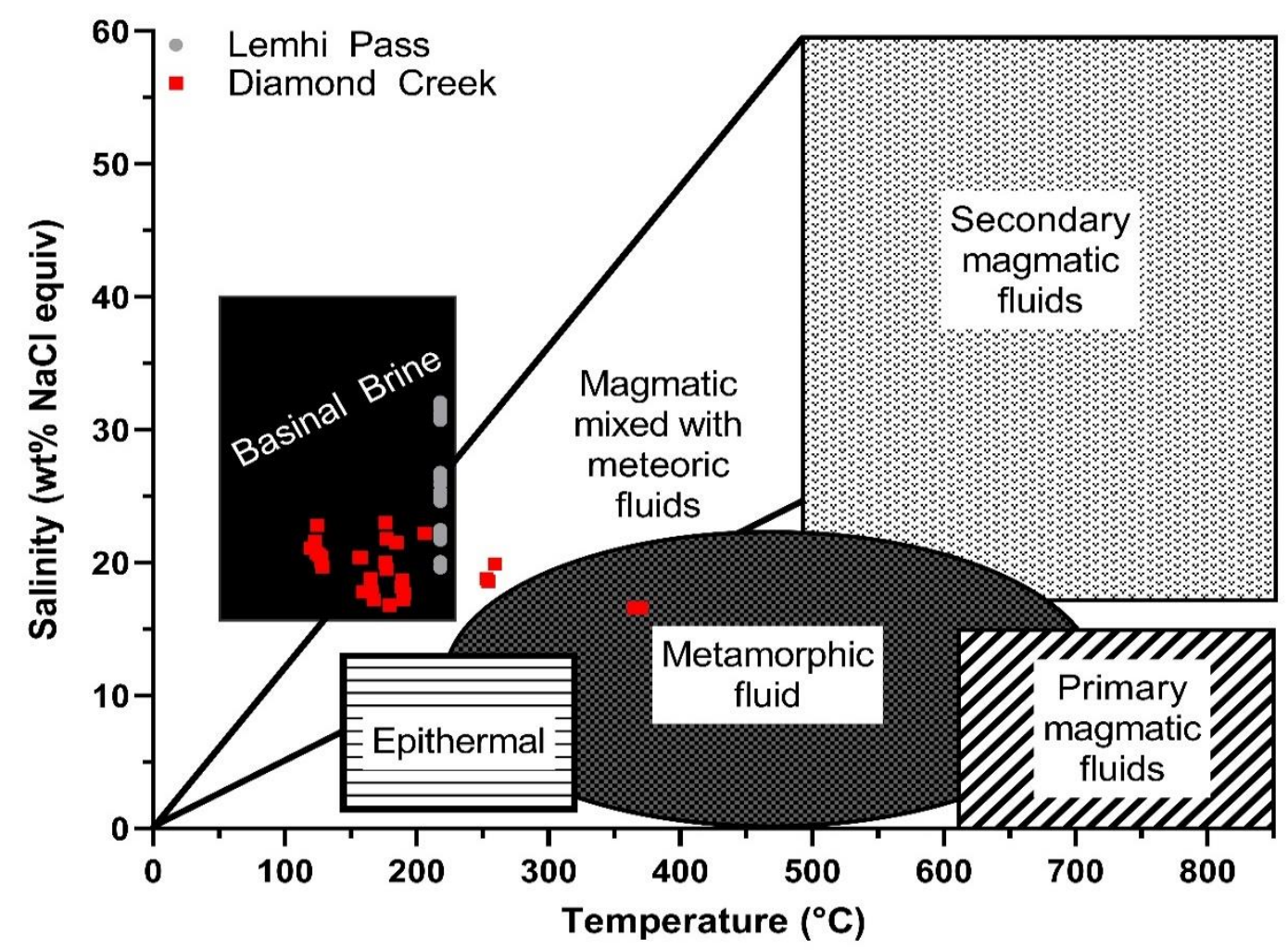

Figure 18: Plot of average salinity and homogenization temperature of fluid inclusion assemblages (FIA's) from Lemhi Pass and Diamond Creek compared to fields of major crustal fluid types as defined by Sharma and Srivastava (2015). Note that if the actual fluid inclusion trapping temperatures were 350 to $525^{\circ} \mathrm{C}$ as suggested by Gibson's (1998) monazite geothermometry, then the Lemhi Pass and Diamond Creek data would plot mainly in the "Magmatic mixed with meteoric fluids" field. Also note that one of the FIA's plots in the metamorphic fluid field, but this FIA is from a post-ore quartz sample.

\section{Discussion}

The results of the present study provide some insights into the nature of the fluids that formed the Lemhi Pass and Diamond Creek Th-REE deposits. The fluids that formed these deposits were brines that fit within the salinity ranges of sedimentary, magmatic, and possibly metamorphic fluids. Homogenization temperatures of fluorite- and 
quartz-hosted fluid inclusions from Diamond Creek and Lemhi Pass, respectively, fit within the temperature range of sedimentary brines, though the trapping temperatures and thus, mineral formation temperatures, could have been significantly higher than the homogenization temperatures.

As noted above, possible evidence for mineral formation temperatures being significantly higher than fluid inclusion homogenization temperatures comes from Gibson (1998), who used monazite geothermometry to calculate an ore formation temperature for Lemhi Pass between 350 and $525^{\circ} \mathrm{C}$. If these temperatures are correct, then they imply a relatively high formation pressure for the ore. This is illustrated by Figure 19, which shows density isochores for Lemhi Pass and Diamond Creek fluid inclusions in pressuretemperature space, modeling them as $\mathrm{NaCl}-\mathrm{H}_{2} \mathrm{O}$ fluids, and calculated using the program, Hokie (Steele-MacInnis et al., 2012). Calculation of the isochores requires knowledge of
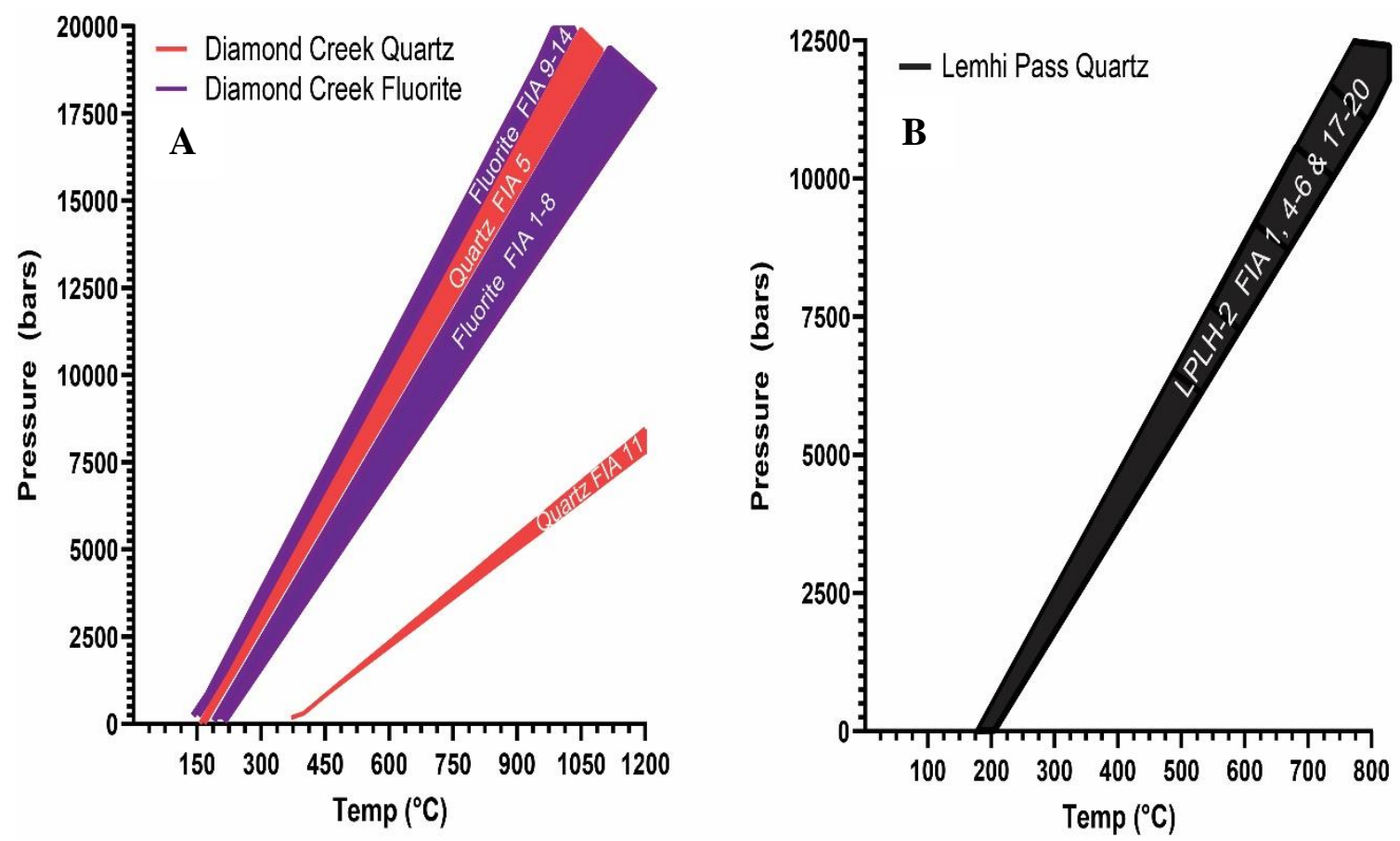

Figure 19: Density isochores determined for (A) Diamond Creek and (B) Lemhi Pass fluid inclusions. The more shallowly sloping isochores in (A) are for fluid inclusions in post-ore quartz. Isochores were calculated using the program, Hokie (Steele-MacInnis et al., 2012). 
fluid inclusion $T_{h}$, which was not known for Lemhi Pass quartz-hosted fluid inclusions because the fluid inclusions decrepitated before homogenizing. However, the vapor bubbles in these fluid inclusions were so small as to be barely visible at the temperature of decrepitation. Thus, the decrepitation temperatures are likely to be a reasonable estimate of $T_{h}$ and were used to calculate the Lemhi Pass quartz-hosted fluid inclusion isochores in Figure 19. Based on the calculated isochore envelopes in Figure 19, the Lemhi Pass and Diamond Creek Th-REE deposits would have formed at pressures between about 2.1 and 5.5 kbars, which are much greater than the pressure of 1 kbar assumed by Gibson (1998), based on the relatively oxidized nature of the mineralization. Pressures of 2.1 to 5.5 kbars could fit with either a sedimentary basin or magmatic environment.

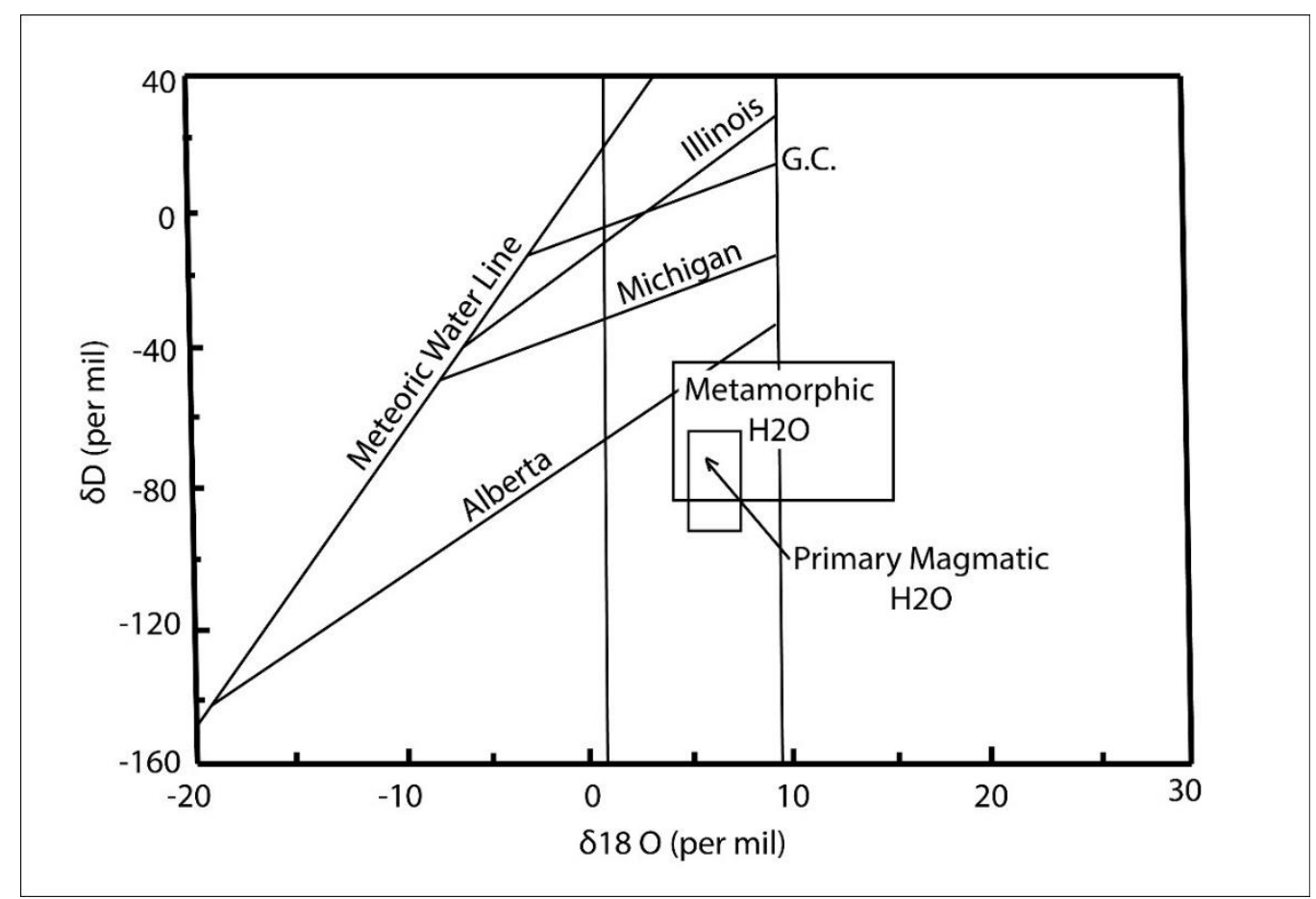

Figure 20: Range of Lemhi Pass ore fluid $\delta^{18} \mathrm{O}$ values determined by Gibson (1998) Plotted relative to the metamorphic and primary magmatic water boxes, meteoric water line, and sedimentary brine trends for the Illinois, Michigan, and Alberta basins (Faure and Mensing, 2005). 
Gibson (2018) also determined the oxygen isotope composition of the Th-REE ore fluids in Lemhi Pass (Fig. 20), which provides more insights into the type of crustal fluid that formed the deposits there. Gibson (1998) found the $\delta^{18} \mathrm{O}$ values to range from about 2 to $9 \%$, which overlaps the isotopically lighter values of the metamorphic water range, encompasses all of the magmatic water range, and intersects the sedimentary basinal brine range. Thus, based on Gibson's (1998) oxygen isotope data, the Lemhi Pass ore fluid cannot be purely magmatic or metamorphic fluid, but could be a mixture of one or both of these fluids with sedimentary brine.

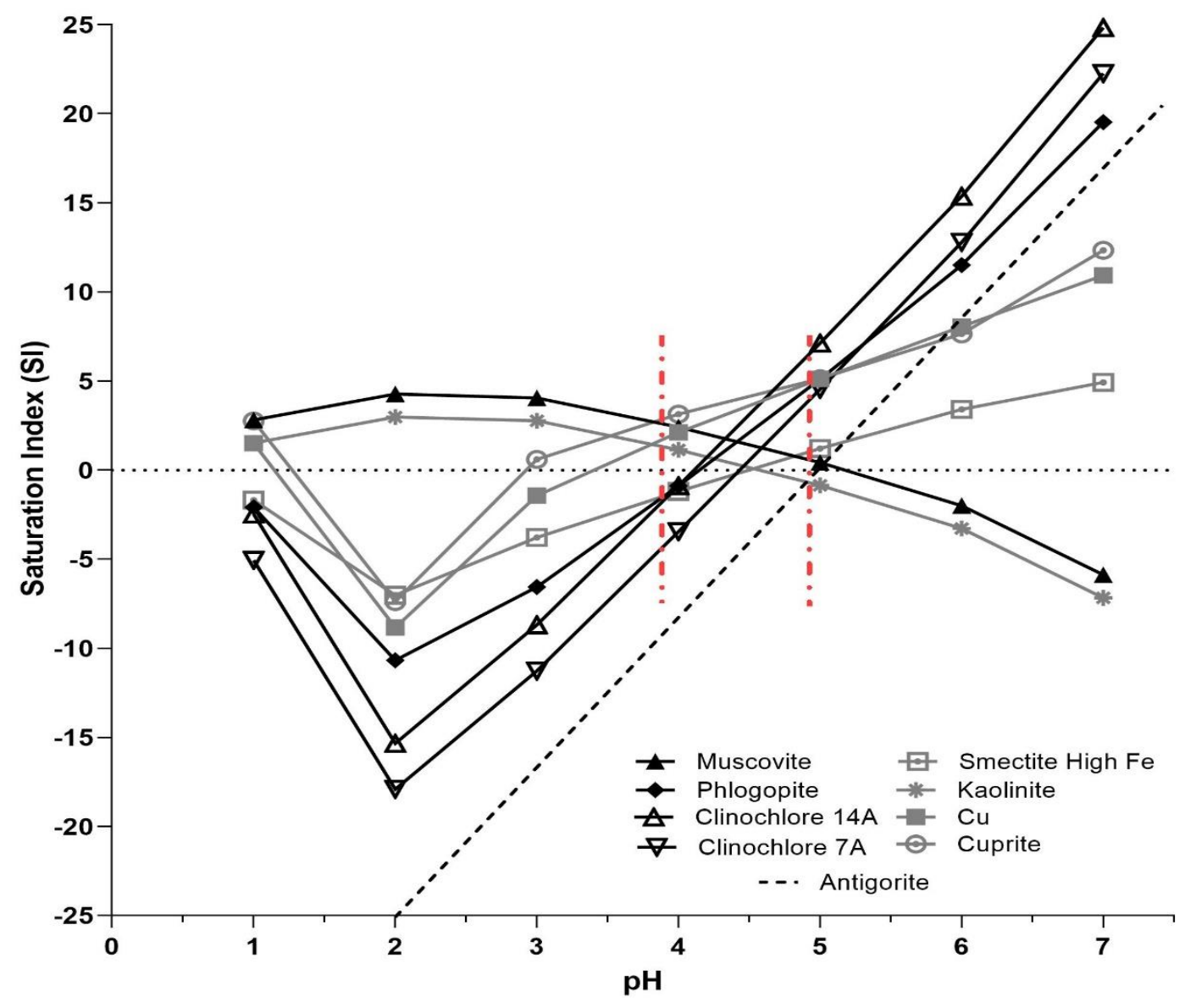

Figure 21: Saturation Index (SI) as a function of $\mathrm{pH}$ at a temperature of $200^{\circ} \mathrm{C}$ for select minerals pertinent to Lemhi Pass ore formation. The vertical red lines in the dash-dot pattern represent the boundaries of the most likely range of $\mathrm{pH}$ for the ore fluid, based on where minerals absent from the hydrothermal mineral assemblage are undersaturated and minerals present in the hydrothermal mineral assemblage are supersaturated. 
Further insights into the formation of the Lemhi Pass and Diamond Creek deposits were sought by interrogating the fluid inclusion data set generated in the present study with geochemical speciation modeling using the Geochemist's Work Bench ${ }^{\circledR}$ software (Bethke, 2006). The speciation models were calculated at temperatures of 200 and
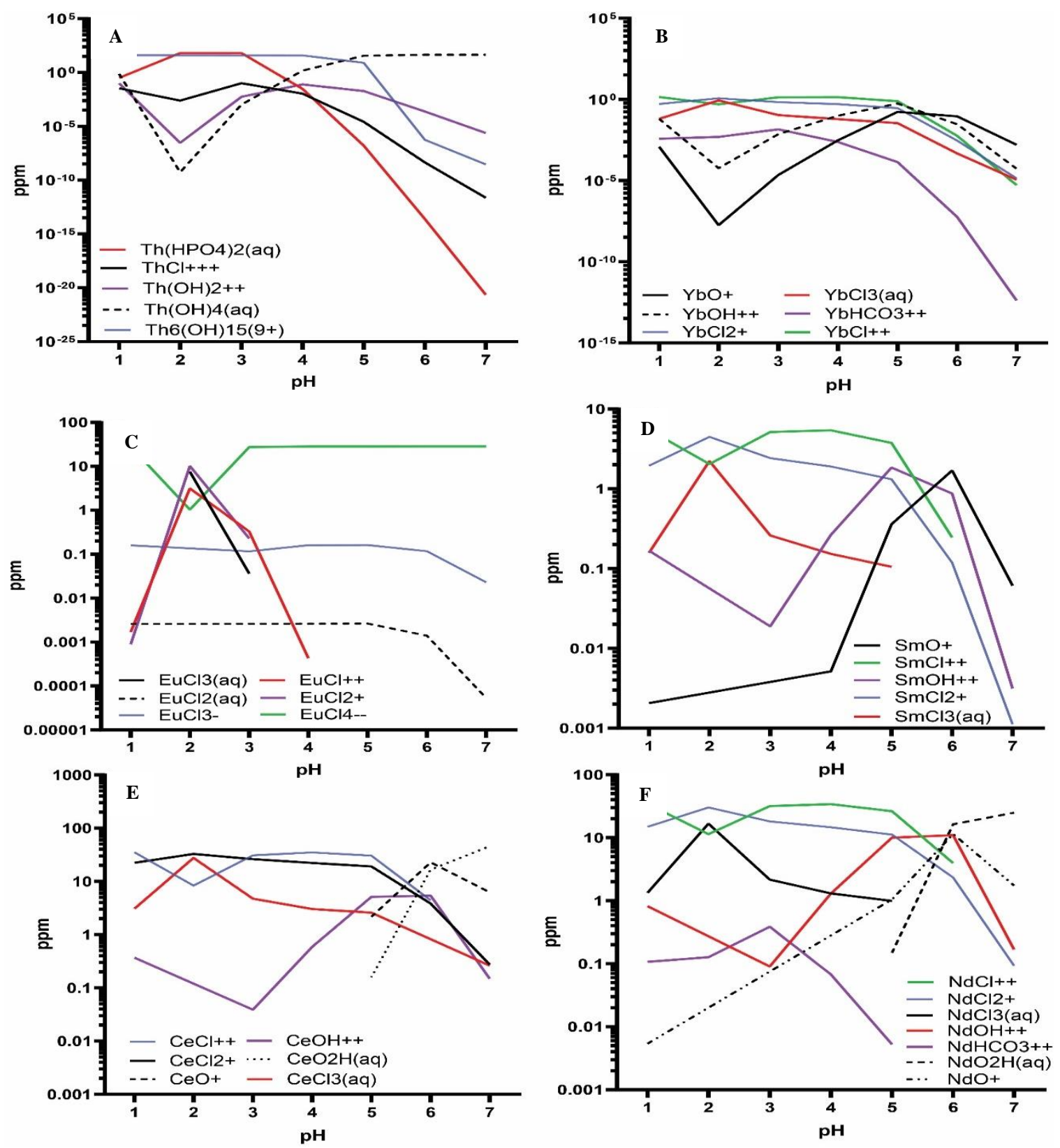

Figure 22: Plots showing the main species in which (A) Th, (B) Yb, (C) Eu, (D) Sm, (E) Ce, and (F) Nd are predicted to occur in aqueous solution in the Lemhi Pass and Diamond Creek ore fluids, with concentrations shown as a function of $\mathrm{pH}$ at a temperature of $200^{\circ} \mathrm{C}$. 
$300^{\circ} \mathrm{C}$, at the saturation pressure of pure water and for a fluid composition shown in Appendix A. Where possible, elemental concentrations were taken from the LA-ICP-MS fluid inclusions analyses. Other elements important to the speciation calculation that were not measured had their concentrations constrained by assuming saturation with respect to minerals present in the hydrothermal ore assemblage.

Figure 21 shows a plot of saturation index for several minerals as a function of $\mathrm{pH}$. This plot helps to constrain the likely $\mathrm{pH}$ of the ore fluid, as certain minerals like native copper and cuprite that are not observed in the Th-REE mineral assemblage must remain undersaturated, whereas other minerals that do appear in the Th-REE mineral assemblage must be supersaturated. These competing criteria are best satisfied in a $\mathrm{pH}$ range of about 3.7 to 4.8 . This is a much more acidic $\mathrm{pH}$ than the near-neutral $\mathrm{pH}$ of 7 suggested by Gibson (1998) for Lemhi Pass.

Figure 22 shows the 5-7 most abundant aqueous species for thorium and each of the REE's measured in the present study. The results show that the REE's in the mineralizing fluids would have existed mainly as chloride complexes over a $\mathrm{pH}$ of 3.7-4.8. Thorium occurs in solution in a more varied form, with hydroxide, phosphate, and chloride complexes all playing a significant role in thorium solubility. These results suggest that dilution could have been an effective way to precipitate REE minerals in Lemhi Pass and Diamond Creek, as dilution would lead to the breakdown of REE-Cl complexes. Dilution could also have promoted thorium precipitation by breaking down $\mathrm{Th}-\mathrm{Cl}$ complexes. Variations in fluid inclusion salinities for Lemhi Pass and Diamond Creek are large enough for dilution possibly to have taken place. In addition, thorium could have been 
precipitated by breaking down $\mathrm{Th}\left(\mathrm{HPO}_{4}\right)_{2}$, which could perhaps have been accomplished by the precipitation of apatite early in the paragenetic sequence.

\section{Conclusions}

The results of the present study provide insights into the nature of the fluid that formed Th-REE mineralization in the Lemhi Pass and Diamond Creek districts. The fluids were brines with salinities ranging from 16.0 to 31.3 wt. \% equiv. Measured homogenization temperatures ranged from 119.5 to $370.5^{\circ} \mathrm{C}$, though many fluid inclusions decrepitated at temperatures lower than their homogenization temperature. If the Lemhi Pass ore formation temperatures of 350 to $525^{\circ} \mathrm{C}$ determined by Gibson (1998) are correct, then this means that the Lemhi Pass and Diamond Creek deposits formed at pressures between 2.1-5.5 kbars, significantly greater than the $1 \mathrm{kbar}$ pressure assumed by Gibson (1998). The composition of the Lemhi Pass and Diamond Creek mineralizing fluids does not unequivocally match any particular crustal fluid type but is most consistent with a mixture of sedimentary brine and magmatic fluid. This magmatic fluid does not bear a clear carbonatite signature, based on comparisons to the Tuva carbonatites and Illinois-Kentucky hybrid MVT-magmatic hydrothermal district.

Chemical speciation modeling suggests that the Lemhi Pass and Diamond Creek mineralizing fluids were moderately acidic, with a likely $\mathrm{pH}$ in the range of 3.7 to 4.8 , which is much more acidic than the near neutral $\mathrm{pH}$ of 7 previously suggested by Gibson (1998). Within this moderately acidic $\mathrm{pH}$ range and given the elemental compositions determined from the LA-ICP-MS analyses, the REE's probably existed in solution mainly as chloride complexes, and thorium existed in solution mainly as chloride, hydroxide, and phosphate complexes. If the mineralizing fluids were diluted, then this 
would have been an effective mechanism for precipitating the REE's and to a lesser extent, thorium. In addition, thorium precipitation could have been aided by diminishing the phosphate concentration of the mineralizing fluid, perhaps by apatite precipitation early in the paragenetic sequence. Boiling does not seem to have played a role in precipitating thorium and the REE's based on insufficient heterogeneity in the liquid: vapor ratios of the fluid inclusions, and because the fluid inclusions only homogenized to liquid and none to vapor. 


\section{References}

Anderson, A.L., (1958). Uranium, thorium, columbium, and rare earth deposits in the Salmon region, Lemhi County, Idaho: Idaho Bureau of Mines and Geology Pamphlet 115 , p. 81

Anderson, A. L., (1961). Thorium mineralization in the Lemhi Pass area, Lemhi County, Idaho. Economic Geology, v. 56, 177-197. doi.org/10.2113/gsecongeo.56.1.177

Denny, F.B., Fifarek, R., and Freiburg, J.,(2017). Geochemical and Petrographic Analysis of the Sparks Hill Diatreme and Its Relationship to the Illinois- Kentucky Fluorspar District: Illinois State Geological Survey, v. 588, p. 1-51.

Bethke, C.M., (2006). The Geochemist's Workbench, version 6.0, a user's guide to Rxn, Act2, Tact, SpecE8, and Aqplot, hydrogeology program. Oxford University Press.

Bodnar, R. J., (1993). Revised equation and table for determining the freezing point depression of H2O-Nacl solutions. Geochimica et Cosmochimica Acta, 57(3), 683684. doi.org/10.1016/0016-7037(93)90378-A

Castor, S. B. (2008). Rare earth deposits of North America. Resource Geology, 58(4), 337347. doi.org/10.1111/j.1751-3928.2008.00068.x

Faure, G., \& Mensing, T. M. (2013). Isotopes: principles and applications $3^{\text {rd }}$ ed. New Delhi: Wiley

Gibson, P. E. (1998). Origin of th Lemhi Pass REE-Th Deposits, Idaho/Montana: Petrology, Mineralogy, Paragenesis, Whole-Rock Chemistry and Isotope Evidence. University of Idaho.

Gillerman, V.S., Jercinovic, M.J., and Stein, H.J., (2002), U-Pb and Re-Os geochronology suggests a multistage Precambrian-Mesozoic history for thorium and copper mineralization, Lemhi Pass, Idaho [abs.]: Geological Society of America Abstracts with Programs, v. 34(6), p. 337

Gillerman, V.S., Lund, Karen, and Evans, K.V. (2003), Stratigraphy, structure, and mineral deposits of the Lemhi Pass area, central Beaverhead Mountains, eastern Idaho, Tobacco Root Geological Society Field Conference at the Belt Symposium IV Northwest Geology, v. 32, p. 134-146. 
Gillerman, V.S., Otto, B., and Griggs, F.S. (2006). Geochronology of Iron Oxide-CopperThorium-REE Mineralization in Proterozoic Rocks at Lemhi Pass, Idaho, and a Comparison to Copper- Cobalt Ores, Blackbird Mining District, Idaho

Gillerman, V.S., Fanning, C.M., Link, P.K., Layer, Paul, and Burmester, R.F.,(2008), Newly discovered intrusives at the Lemhi Pass thorium-REE iron oxide district, Idaho: Cambrian syenite and mystery ultramafics - Signatures of a buried alkaline complex or two systems? Geological Society of America Abstracts with Programs, v. 40 , no. 1 , p. 51.

Gosen, B. S. Van, Gillerman, V. S., \& Armbrustmacher, T. J. (2009). Thorium Deposits of the United States - Energy Resources for the Future? U.S. Geological Circular 1336 .

Hanor, J.S., (1996). Controls on the solubilization of lead and zinc in basinal brines. Carbonate-hosted Lead-Zinc Deposits, SEG Special Publication: USA, v. 4, pp.483500.

Hedrick, J.B.,(2007), Rare Earths: U.S. Geological Survey Minerals Yearbook, p. 60.160.18, doi:10.1016/j.ecolecon.2008.01.027.

Jones, A.P., Genge, M., and Carmody, L., (2013), Carbonate melts and carbonatites: Reviews in Mineralogy and Geochemistry, v. 75, p. 289-322, doi:10.2138/rmg.2013.75.10.

Lawler, J.P., and Crawford, L., (1983). Stretching of Fluid Inclusions Resulting from a Low-temperature Microthermometric Technique: Economic Geology, v. 78, p. 527529.

Lewis, R.S., Gillerman, V.S., Burnmester, R.F., Mosolf, J. and Lonn, J.D., (2017). Road Log to the Geology and Moineralization of the Agency Creek and Lemhi Pass Areas, Idaho and Montana. Northwest Geology, v. 46, p.119-132.

Long, K. R., Van Gosen, B. S., Foley, N. K., \& Cordier, D., (2012). The principal rare earth elements deposits of the United States: A summary of domestic deposits and a global perspective. Non-Renewable Resource Issues: Geoscientific and Societal Challenges, p. 131-155. doi.org/10.1007/978-90-481-8679-2_7 
Mutchler, S.R., Fedele L., Bodnar R.J., (2008). Appendix A5: Analysis management system (AMS) for reduction of laser ablation ICP-MS data. In: Sylvester P (ed) Laser ablation (ICP-MS) in the earth sciences: Current practices and outstanding issues. Mineralogical Association of Canada Short Course Series, v.40, pp 318-327.

Prokopyev, I.R., Borisenko, A.S., and Borovikov, A.A., (2012). LA-ICP-MS investigations of ore-forming fluids of Fe-F-REE carbonatite deposits of Central Tuva region, Russia, 4th Biennial Conference on Asian Current Research on Fluid Inclusions ACROFIIV, p. 61-62.

Sharma, R., and Srivastava, P.K.,(2014). Hydrothermal Fluids of Magmatic Origin: , p. 122, doi:10.1007/978-3-319-06471-0.

Staatz, M. H. (1972). Geology and Description of the Thorium-Bearing Veins, Lemhi Pass Quadrangle, Idaho and Montana. Washington, D.C.. Library of Congress

Staatz, M. H. (1979). Geology and Mineral Resources of the Lemhi Pass Thorium District, Idaho and Montana. Washington, D.C.: U.S. Department of the Interior

Staatz, M. H., Shaw, V. E., \& Wahlberg, J. S. (1972). Occurrence and distribution of rare earths in the Lemhi Pass thorium Veins, Idaho and Montana. Economic Geology, 67(1), 72-82. doi.org/10.2113/gsecongeo.67.1.72

Steele-MacInnis, M., Lecumberri-Sanchez, P., Bodnar, R.J.,(2012). HOKIEFLINCS_H2ONACL: A Microsoft Excel spreadsheet for interpreting microthermometric data from fluid inclusions based on the PVTX properties of $\mathrm{H} 2 \mathrm{O}-\mathrm{NaCl}$. Computers \& Geosciences

Sterner, S.M., Hall, D.L., and Bodnar, R.J., (1988). Synthetic fluid inclusions. V. Solubility relations in the system $\mathrm{NaCl}-\mathrm{KCl}-\mathrm{H} 2 \mathrm{O}$ under vapor-saturated conditions: Geochimica et Cosmochimica Acta, v. 52, p. 989-1005, doi:10.1016/00167037(88)90254-2.

Sverjensky, D.A., (1984). Oil field brines as ore-forming solutions.: Economic Geology, v. 79, p. 23-37, doi:10.2113/gsecongeo.79.1.23.

Taylor, S.R. and McLennan, S.M., (1985). The Continental Crust; Its composition and evolution; an examination of the geochemical record preserved in sedimentary rocks. Blackwell, Oxford. 312. 
Yardley, B.W.D., (2005), 100th Anniversary Special Paper: Metal concentrations in crustal fluids and their relationship to ore formation: Economic Geology, v. 100, p. 613632, doi:10.2113/gsecongeo.100.4.613. 


\section{Appendix A}

Fluid Composition Used in Chemical Speciation Modeling

\begin{tabular}{|c|c|c|}
\hline $\mathrm{H} 2 \mathrm{O}$ & $\begin{array}{l}1.0 \\
\end{array}$ & free $\mathrm{kg}$ \\
\hline $\mathrm{Na}+$ & 19457.5 & $\mathrm{mg} / \mathrm{kg}$ \\
\hline $\mathrm{Mg++}$ & 11635.3 & $\mathrm{mg} / \mathrm{kg}$ \\
\hline $\mathrm{K}_{+}$ & 4226.4 & $\mathrm{mg} / \mathrm{kg}$ \\
\hline $\mathrm{Ca}++$ & 62123.9 & $\mathrm{mg} / \mathrm{kg}$ \\
\hline $\mathrm{Zn++}$ & 12968.8 & $\mathrm{mg} / \mathrm{kg}$ \\
\hline Th++++ & 34.8 & $\mathrm{mg} / \mathrm{kg}$ \\
\hline Cu++ & 461.3 & $\mathrm{mg} / \mathrm{kg}$ \\
\hline $\mathrm{Rb}+$ & 134.5 & $\mathrm{mg} / \mathrm{kg}$ \\
\hline $\mathrm{Sr}++$ & 77.0 & $\mathrm{mg} / \mathrm{kg}$ \\
\hline $\mathrm{Ce}+++$ & 45.3 & $\mathrm{mg} / \mathrm{kg}$ \\
\hline $\mathrm{Nd}+++$ & 39.4 & $\mathrm{mg} / \mathrm{kg}$ \\
\hline Sm+++ & 6.1 & $\mathrm{mg} / \mathrm{kg}$ \\
\hline Eu+++ & 14.8 & $\mathrm{mg} / \mathrm{kg}$ \\
\hline Yb+++ & 1.8 & $\mathrm{mg} / \mathrm{kg}$ \\
\hline $\mathrm{Fe}++$ & 839.7 & $\mathrm{mg} / \mathrm{kg}$ \\
\hline $\mathrm{Pb}++$ & 165.4 & $\mathrm{mg} / \mathrm{kg}$ \\
\hline Cl- & 10000.0 & $\mathrm{mg} / \mathrm{kg}$ \\
\hline $\mathrm{Ti}(\mathrm{OH}) 4(\mathrm{aq})$ & 961.0 & $\mathrm{mmol} / \mathrm{kg}$ \\
\hline Fluorapatite (F-) & 1.0 & $\begin{array}{c}\text { free } \\
\mathrm{mmol} / \mathrm{kg}\end{array}$ \\
\hline $\begin{array}{l}\text { Hydroxlapatite } \\
\text { (HPO4--) }\end{array}$ & 1.0 & $\begin{array}{c}\text { free } \\
\mathrm{mmol} / \mathrm{kg}\end{array}$ \\
\hline Hematite & 1.0 & $\begin{array}{c}\text { free } \\
\mathrm{mmol} / \mathrm{kg}\end{array}$ \\
\hline Quartz & 1.0 & $\begin{array}{c}\text { free } \\
\mathrm{mmol} / \mathrm{kg}\end{array}$ \\
\hline Dolomite & 1.0 & $\begin{array}{c}\text { free } \\
\mathrm{mmol} / \mathrm{kg}\end{array}$ \\
\hline K-Feldspar & 1.0 & $\begin{array}{c}\text { free } \\
\mathrm{mmol} / \mathrm{kg}\end{array}$ \\
\hline Temperature & $200 \& 300$ & ${ }^{\circ} \mathrm{C}$ \\
\hline $\mathrm{H}_{+}$ & variable & $\mathrm{pH}$ \\
\hline
\end{tabular}

